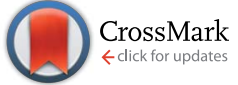

Cite this: RSC Adv., 2014, 4, 38726

\title{
2,3-Diaryl-substituted indole based COX-2 inhibitors as leads for imaging tracer development $\uparrow$
}

\author{
Markus Laube, ${ }^{\text {ab }}$ Christoph Tondera, ${ }^{\text {ab }}$ Sai Kiran Sharma, ${ }^{c}$ Nicole Bechmann, ${ }^{\text {ab }}$ \\ Franz-Jacob Pietzsch, ${ }^{\text {ad }}$ Arne Pigorsch, ${ }^{e}$ Martin Köckerling, ${ }^{\text {e }}$ Frank Wuest, ${ }^{c}$ \\ Jens Pietzsch*ab and Torsten Kniess ${ }^{\star a}$
}

A series of 2,3-diaryl-substituted indoles containing a fluorine or methoxy group was synthesized via Fischer indole synthesis, McMurry cyclization, or Bischler-Möhlau reaction to identify potential leads for positron emission tomography (PET) radiotracer development as well as for optical imaging. All 2,3-diarylsubstituted indoles possess autofluorescent properties with an emission maximum in a range of 443$492 \mathrm{~nm}$, which is acceptable for biological studies in vitro and, in part, in vivo. The molecular structure of compounds $3 \mathrm{a}$ and $3 \mathrm{j}$ was confirmed by X-ray crystal structure analysis. COX inhibitory activity was evaluated by a fluorescence-based and enzyme immunoassay-based assay. Redox activity of all target compounds was also determined. All synthesized 2,3-diaryl-substituted indoles are inhibitors of COX-2 enzyme in the low micromolar range. Compounds $3 \mathrm{e}, 3 \mathrm{f}, 3 \mathrm{~g}$ and $3 \mathrm{~m}$ displayed a $30-40 \%$ inhibition of COX-2 at $0.1 \mu \mathrm{M}$ concentration while compounds $3 \mathrm{f}$ and $3 \mathrm{~g}$ also exhibited COX-1 inhibitory activity. Various compounds like $3 \mathrm{~g}$ showed substantial antioxidative potential ( $R_{\text {DIENE }}=2.85, R_{\text {HAVA }}=1.98$ ), an effect that was most measurable with methoxy-substituted compounds. With respect to PET radiotracer synthesis, OMe-containing compound $3 \mathbf{j}$ was selected as a promising candidate for carbon-11 labeling, and $\mathrm{F}$-containing compound $3 \mathrm{~m}$ as a lead for the development of a fluorine-18 labeled derivative.

Received 12th June 2014 Accepted 13th August 2014 DOI: $10.1039 / \mathrm{c} 4 \mathrm{ra05650g}$ www.rsc.org/advances

\section{Introduction}

Since the discovery of the cyclooxygenase-2 (COX-2) isoenzyme in the early 1990s it has been well accepted that this isoform of cyclooxygenases plays an essential role in a number of various (patho)physiological processes such as chronic inflammatory diseases, neurodegenerative disorders, and cancer. Both isoforms (COX-1 and COX-2) catalyze the conversion of arachidonic acid into prostaglandin $\mathrm{H}_{2}\left(\mathrm{PgH}_{2}\right)$, which subsequently

${ }^{a}$ Department Radiopharmaceutical and Chemical Biology, Institute of Radiopharmaceutical Cancer Research, Helmholtz-Zentrum Dresden-Rossendorf, 01328 Dresden, Germany. E-mail: t.kniess@hzdr.de; j.pietzsch@hzdr.de; Tel: +493512602760; +493512602622

${ }^{b}$ Department of Chemistry and Food Chemistry, Technische Universität Dresden, 01062 Dresden, Germany

'Department of Oncology, Cross Cancer Institute, University of Alberta, Edmonton, Alberta, Canada T6G 1 Z2

${ }^{d}$ Centre for Translational Bone, Joint, and Soft Tissue Research, Medical Faculty and University Hospital, Technische Universität, 01307 Dresden, Germany

${ }^{e}$ Department of Inorganic Solid State Chemistry, Institute of Chemistry, University of Rostock, Albert-Einstein-Str. 3a, 18059 Rostock, Germany

$\dagger$ This work is dedicated to the $75^{\text {th }}$ birthday of Prof. Dr Bernd Johannsen.

\$ Electronic supplementary information (ESI) available. CCDC 963601, 963602, 963609 and 963572. For ESI and crystallographic data in CIF or other electronic format see DOI: 10.1039/c4ra05650g leads to the biosynthesis of prostaglandins and thromboxanes as mediators of a variety of important physiological functions like vasodilation, regulation of inflammatory response, and platelet aggregation. While COX-1 is constitutively expressed, COX-2 is nearly absent under normal physiological conditions. However, various inflammatory stimuli induce COX-2 expression and function. In a clinical picture, overexpression of COX-2 leads to high levels of eicosanoids resulting in acute inflammation, pain and fever. Hence, inflammation is treated by inhibition of COX-2. First generation of COX inhibitors are termed as non-steroidal anti-inflammatory drugs (NSAIDs), which target both COX-1 and COX-2. Typical examples of NSAIDs represent ibuprofen, indomethacin, and diclofenac. COX-1 inhibition through NSAIDs can cause undesirable side effects such as peptic ulcer or stomach bleeding. To overcome these drawbacks, a second generation of compounds, termed as COXIBs, was developed. COXIBs like celecoxib, valdecoxib, and rofecoxib are characterized by high $\mathrm{COX}-2 / \mathrm{COX}-1$ selectivity profile. These selective COX-2 inhibitors bind competitively to the cyclooxygenase active site of COX-2, but not COX-1, and hence block COX-2-mediated prostaglandin synthesis. Later it became clear that complete inhibition of COX-2 also blocks the formation of vasodilators like prostaglandin $I_{2}$ and, consequently, resulted in a shift from the COX pathway to the lipoxygenase pathway. This shift was accompanied with increased 
cardiovascular risk. This matter of facts demonstrates that the search of new lead structures with high COX-2 selectivity but without cardiac or other side effects is an ongoing research field. ${ }^{1}$

Most COXIBs are characterized by a central five membered heterocyclic core structure (pyrrole, thiazole, oxazole, furan and imidazole) with two adjacent aromatic rings bearing a methylsulfonyl or aminosulfonyl group as COX-2 pharmacophore. This basic concept was extended for the design of new lead structures possessing a six-membered or bicyclic heterocyclic core. ${ }^{2,3}$ The indole motif is a classical pharmacophore present in the non-selective COX inhibitor indomethacin which was as corestructure for the design of various selective COX-2 inhibitors reported by Black et al. (Scheme 1). ${ }^{4}$ Later, novel $N$-substituted indole carboxyclic acid esters, ${ }^{5}$ and various 3,6- and 2,6-disubstituted indole derivatives were described as potent and selective COX-2 inhibitors. ${ }^{6-8}$ Particularly high potent and selective COX-2 inhibitors as 2,3-diaryl substituted indoles were reported by $\mathrm{Hu}$ and Guo et al. $^{9-11}$ Moreover, quantitative structureactivity relationship (SAR) analysis on benzyl-substituted indoles demonstrated a correlation of the C-2 and C-3 substitution pattern with the found high COX-2 inhibitory and selectivity profile. ${ }^{12}$ More recently, Kaur et al. ${ }^{\mathbf{1 3}}$ discussed various $\mathrm{N}-1$ and $\mathrm{C}-3$ substituted indole Schiff bases as selective COX-2 inhibitors. A selection of potent and selective COX-2 inhibitors based on indoles is depicted in Scheme 1.

Over the last years, COX-2 has also been associated with the development and progression of cancer. Elevated COX-2 levels are found in many human epithelium-derived malignancies. This finding correlates with aggressiveness, metastatic and invasive potential of tumors. ${ }^{\mathbf{1 4 , 1 5}}$ Exemplarily, human malignant melanoma, a non-epithelial tumor that is characterized by a marked inflammatory response and high metastatic potential, has been shown to overexpress COX-2, ${ }^{16,17}$ and COX-2 was proposed as a prognostic marker in melanomata and also in various epithelial tumors. ${ }^{18-21}$ Consequently, tumor-promoting inflammation has been recognized as an emerging hallmark of cancer, and is a current therapeutic target for the development of anticancer drugs. ${ }^{22}$

Current anticancer drug design and discovery increasingly includes non-invasive molecular imaging methodologies to assess efficacy of novel drugs based on their molecular mode of action. We are interested in radionuclide-guided functional molecular imaging of COX-2 by means of positron emission tomography (PET). The use of selective COX-2 inhibitors as PET radiotracers for molecular imaging of COX-2 would provide valuable information on tumor prognosis, metastasis, or therapy response. ${ }^{23-25}$

Up to now, a number of radiotracers basing on clinically used COXIBs like celecoxib and valdecoxib have been described;26,27 as well as novel compounds with hitherto unknown pharmacological profile were synthesized, radiolabeled and evaluated in vitro and in vivo. ${ }^{24}$ Some recent studies with ${ }^{18} \mathrm{~F}$-labeled pyrazole ${ }^{28}$ or azulene $\mathrm{e}^{29}$ based COX-2 inhibitors have successfully demonstrated a specific uptake of radiolabeled COX-2 probes in inflammatory lesions as well as in xenografted tumors and gave the proof of principle of targeting COX-2 in vivo with radiotracers. However, despite of promising pre-clinical results a suitable COX-2 specific radiotracer for human use is still absent, a fact that is stimulating radiopharmaceutical research in that field.

In our efforts to develop radiolabeled COX-2 inhibitors we selected 2,3-diaryl-substituted indole as lead structure, and we recently reported on the radiosynthesis and radiopharmacological evaluation of $3-\left(4-\left[{ }^{18} \mathrm{~F}\right]\right.$ fluorophenyl)-2-(4methylsulfonylphenyl)- $1 H$-indole as novel ${ }^{18} \mathrm{~F}$-radiotracer for PET imaging of COX-2. Although the radiotracer displayed a promising in vitro and in vivo stability profile, no uptake into COX-2-expressing human HT-29 tumor xenografts transplanted in NMRI nu/nu mice could be observed. ${ }^{30}$ We concluded that the COX-2 inhibitory activity and selectivity profile of the compound in vivo was not suitable for radiotracer applications. However, potential of varying the $\mathrm{C}-2 / \mathrm{C}-3$ substitution pattern in the indole scaffold as well as the innovative and highly effective radiosynthesis via McMurry cyclization prompted us to synthesize a comprehensive series of 2,3-diaryl-substituted indoles containing fluorine or methoxy groups as leads for the development of respective ${ }^{11} \mathrm{C}$ - and ${ }^{18} \mathrm{~F}$-radiolabeled PET radiotracers. The motivation of the present work was to identify from a pool of 2,3-diaryl-substituted indoles one or two candidates with nanomolar affinity towards COX-2, most favorable COX-2/COX-1 selectivity, having fluorine or methoxy
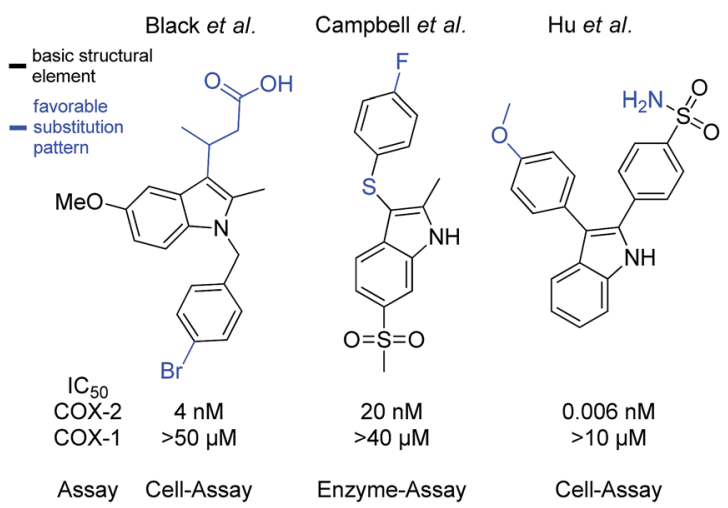

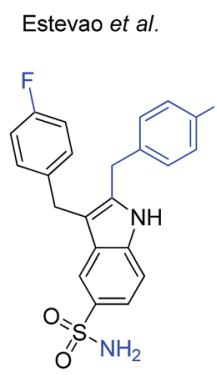

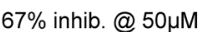
18\% inhib. @ 50 $\mu \mathrm{M}$

Enzyme-Assay

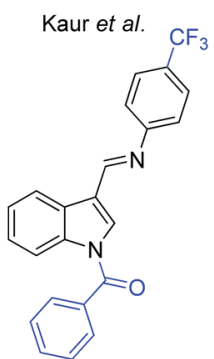

$0.32 \mu \mathrm{M}$

$>100 \mu \mathrm{M}$

Enzyme-Assay

Scheme 1 Potent COX-2 inhibitors containing an indole motif. 
substituents suitable to be replaced by fluorine-18 or carbon-11 respectively.

In this paper we describe the synthesis of thirteen 2,3-diarylsubstituted indoles. We in detail assessed their chemical and fluorescent spectroscopic characteristics. All compounds were screened for their COX-2 inhibitory activity and selectivity profile using a fluorescence-based and an enzyme immunoassay-based COX assay. Many indoles possess antioxidative properties which is an important parameter for their exerted biological activity profile. Antioxidative potential of novel indole compounds was assessed and compared with prominent indole-based antioxidant melatonin. ${ }^{31,32}$ Concluding SAR studies assisted us in the selection of suitable candidates for radiotracer development.

\section{Results and discussion}

\section{Chemistry}

The synthetic routes towards 2,3-diaryl-substituted indoles are shown in Schemes 2 and 4, both follow in general literature procedures which however have been improved and modified by us for higher yields and products purity.

The synthesis of 2-sulfonylphenyl-3-phenyl- $1 H$-indoles $\mathbf{3 a}-\mathbf{3 g}$ (Scheme 2) followed the synthetic strategy of $\mathrm{Hu}$ et al. ${ }^{\mathbf{1 0}}$ involving a McMurry cyclization as the final step to build up the indole core structure. For this approach the benzophenone derivatives 1a-1d served as starting materials. Compounds 1a and $1 \mathrm{~d}$ were obtained in $25 \%$ and $21 \%$ yield, respectively, from $\mathrm{N}$-tosyl protected anthranilic acid by conversion into the corresponding acid chloride with $\mathrm{PCl}_{5}$ and subsequent reaction with fluorobenzene or anisole under Friedel-Crafts conditions followed by detosylation using a mixture of acetic acid and perchloric acid. ${ }^{30,33}$ Compounds $\mathbf{1 b}$ and $\mathbf{1 c}$ were synthesized in one step by Friedel-Crafts acylation using $\mathrm{BCl}_{3}$ to achieve selective ortho-benzoylation relative to the amino residue. ${ }^{34}$ Following this route by starting from $p$-toluidine and $p$-fluorobenzonitrile, $\mathbf{1 b}$ was obtained in $21 \%$ yield. Comparable to that, the yield for $1 \mathrm{c}$ was $23 \%$ but it should be noted that the hydroxy derivative 1c was obtained unexpectedly by using $p$-anisidine and $p$-fluorobenzonitrile for the synthesis of the methoxy derivative. Apparently under the used reaction conditions, boron trichloride caused a demethylation of $p$-anisidine so that the hydroxy derivative 1c was formed. Since similar but slightly milder reaction conditions were used by Dinsmore and Berg$\operatorname{man}^{35}$ for the synthesis of 2-amino-3'-fluoro-5-methoxy-benzophenone, we also applied this procedure for the synthesis of the methoxy derivative but no product was formed. We assumed that the methoxy-derivative was not directly accessible by this route and we applied the Bischler-Möhlau synthesis as shown below to get access to a 5-methoxy-substituted indole. As a second note, 1c was not stable in alkaline solution during workup so that for isolation of 1c neutralization of the reaction mixture with $\mathrm{NaHCO}_{3}$ and extraction before column chromatography was applied. The amino substituted benzophenones 1a-1d were converted into the $N$-(2-benzoyl)phenyl-benzamides $2 \mathbf{a}-2 \mathbf{g}$ by reaction with the corresponding methylsulfonyl- or aminosulfonyl-substituted benzoyl chloride and $\mathrm{Et}_{3} \mathrm{~N}$ in THF in $62-96 \%$ yield. In the final step, the benzamides $2 \mathbf{a}-\mathbf{2 g}$ were cyclized under McMurry conditions to yield the 2,3-diarylsubstituted indoles $3 \mathbf{a}-\mathbf{2} \mathrm{g}$ in $21-85 \%$.

From 3-(fluorophenyl)-2-[4-(methylsulfonyl)phenyl]-1 $H$-indole (3a) crystals suitable for X-ray structure analysis could be obtained by slow evaporation of a solution of $\mathbf{3 a}$ in ethyl acetate at room temperature. This unambiguously confirmed the molecular structure of the compound (Fig. 1, for detailed results including the X-ray structure analysis of the intermediate $2 \mathrm{c}$ see the Experimental section and the ESI + . Interestingly, the plane of the methylsulfonyl-substituted phenyl ring in compound $\mathbf{3 a}$ is only slightly twisted out of the plane of the indole core (dihedral angle: $26.74^{\circ}$ ) in comparison to the fluoro-substituted phenyl ring (dihedral angle: $52.89^{\circ}$ ). This gives evidence for the preferential interaction of the electron-rich indole system with the electron-deficient methylsulfonyl-substituted phenyl ring.

The synthesis of the sulfonyl acetamide derivative $\mathbf{3 h}$ was accomplished by the reaction of compound $\mathbf{3 g}$ with acetyl chloride in acetic acid at $90{ }^{\circ} \mathrm{C}$ in $70 \%$ yield (Scheme 3 ).

The 3-sulfonylphenyl-2-phenyl indoles $\mathbf{3 i - 3 1}$ were synthesized by application of a Fischer indole synthesis following the

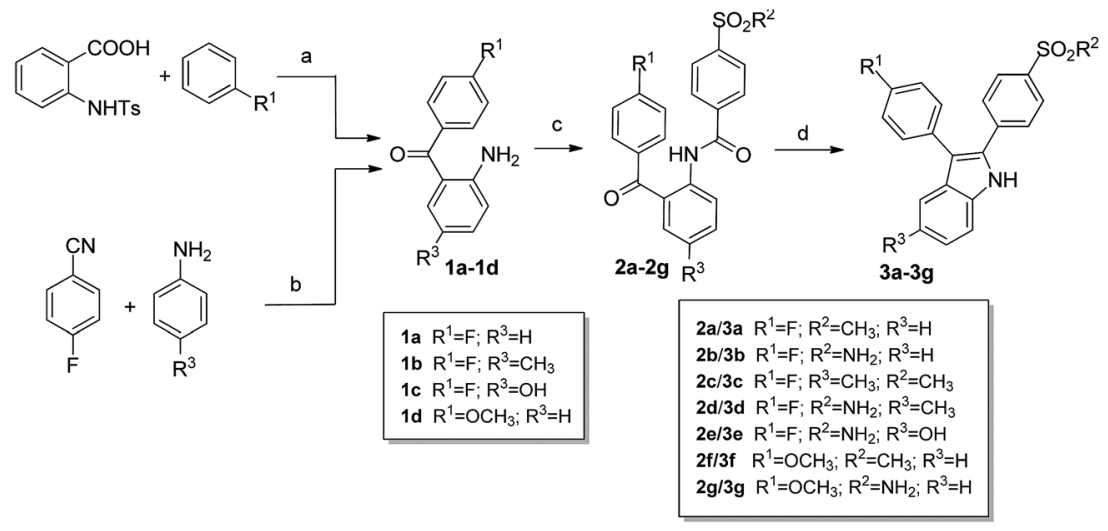

Scheme 2 Synthesis of 2-sulfonylphenyl substituted indoles $3 a-3 g$ by McMurry cyclization. Reagents and conditions: (a) for $1 \mathrm{a}$ and $1 \mathrm{~d}$ : (i) PCl ${ }_{5}$, $50{ }^{\circ} \mathrm{C}$, (ii) $\mathrm{AlCl}_{3}, 80^{\circ} \mathrm{C}$ (1a) and $5-10{ }^{\circ} \mathrm{C}$ (1d), (iii) $\mathrm{HClO}_{4} / \mathrm{CH}_{3} \mathrm{COOH}, 100{ }^{\circ} \mathrm{C}$; (b) for $1 \mathrm{~b}-1 \mathrm{c}$ : (i) $\mathrm{BCl}_{3}, \mathrm{AlCl}_{3}$, toluene, reflux, (ii) $2 \mathrm{M} \mathrm{HCl}$, reflux; (c) 4 $\left(\mathrm{R}^{2} \mathrm{O}_{2} \mathrm{~S} \mathrm{C}_{6} \mathrm{H}_{4} \mathrm{COCl}, \mathrm{NEt}_{3}, \mathrm{THF}, \mathrm{rt} ;\right.$ (d) $\mathrm{TiCl}_{4}, \mathrm{Zn}, \mathrm{THF}, 65^{\circ} \mathrm{C}$. 


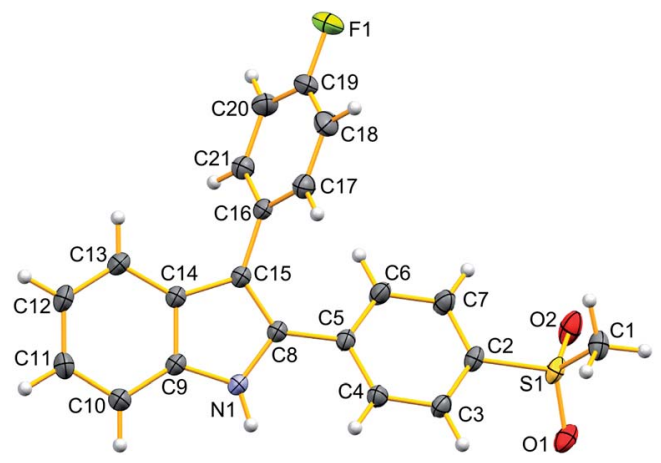

Fig. 1 Molecular structure of compound 3a in the crystal (ORTEP plot: displacement thermal ellipsoids are drawn at 50\% probability level).

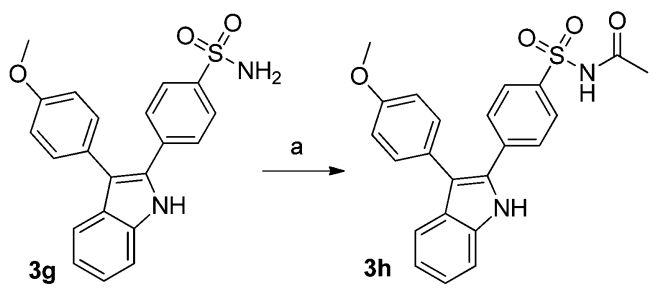

Scheme 3 Synthesis of compound $3 \mathrm{~h}$ by acetylation. Reagents and conditions: (a) $\mathrm{CH}_{3} \mathrm{COCl}, \mathrm{CH}_{3} \mathrm{COOH}$, reflux.

synthetic strategy of Guo et al. ${ }^{11}$ (Scheme 4). For that purpose, 1phenyl-2-sulfonylphenyl ethanones 5a-5d served as key intermediates. The methylsulfonyl-substituted compounds $\mathbf{5 a - 5 c}$ were obtained starting from 4-(methylsulfonyl)phenylacetic acid by conversion to its acid chloride with $\mathrm{SOCl}_{2}$ and subsequent reaction under Friedel-Crafts conditions with ethoxybenzene, anisole, and fluorobenzene, respectively (for detailed results of X-ray crystal structure analysis of the intermediate $\mathbf{5 c}$ see the Experimental section and the ESI:) ${ }^{36}$ The sulfamoylsubstituted ethanone 5d was synthesized in two steps: 1-(4fluorophenyl)-2-phenylethanone (4) was prepared in a yield of $51 \%$ by Friedel-Crafts reaction of phenylacetic acid chloride and fluorobenzene as described by Singh $e t$ al. ${ }^{37}$ followed by a chlorosulfonylation and ammonolysis at the para-position of the 2-phenyl ring. In detail this was performed by utilization of pure chlorosulfuric acid at temperatures about $-78{ }^{\circ} \mathrm{C}$ rising slowly to room temperature and subsequent reaction of the crude product in ethyl acetate with aqueous ammonia solution what gave the desired product $\mathbf{5 d}$ in $34 \%$ yield. ${ }^{38}$ Compounds 5a-5d were then converted into the appropriate 3-sulfonylphenyl-2-phenyl- $1 H$-indoles $3 \mathbf{i}-\mathbf{3 l}$ by Fischer indole synthesis using phenylhydrazine and $\mathrm{BF}_{3} \cdot \mathrm{Et}_{2} \mathrm{O}$ as Lewis acid. However, the low yields about $20 \%$ prompted us to test the synthesis of $3 \mathbf{j}$ exemplarily by the McMurry pathway. For that, 2-amino- $4^{\prime}$ (methylsulfonyl)benzophenone was allowed to react with 4methoxybenzoyl chloride to form $\mathrm{N}$-[2-(4-(methylsulfonyl)benzoyl)phenyl]-4-methoxybenzamide which was subsequently and without isolation of the intermediate reacted under McMurry conditions in a two step/one-pot procedure (Scheme 5) as described by $\mathrm{us}^{39}$ for the syntheses of 2-carbaboranyl-substituted indoles. This approach gave $\mathbf{3} \mathbf{j}$ in slightly better $32 \%$ yield over two steps. Crystals suitable for X-ray structure analysis could be obtained from a solution of $3 \mathbf{j}$ in ethyl acetate-petroleum ether $50: 50$ by slow evaporation at room temperature which unambiguously revealed the molecular structure of $\mathbf{3 j}$ (Fig. 2, for detailed results see the Experimental section and the ESI:). Interestingly, in this compound the molecular geometry differs in comparison to 3a. The plane of the phenyl ring in 2-position is substantially twisted out of the plane of the indole-core (dihedral angle: $52.89^{\circ}$ ), likely due to the electron-rich methoxy-substituent in para-position. Consistently although not as stabilized as in compound 3a, the methylsulfonyl-substituted phenyl ring is again less twisted out of the plane of the indole core (dihedral angle: $39.62^{\circ}$ ) compared to the neighboring phenyl ring.

As shown before, demethylation during the $\mathrm{BCl}_{3}$-mediated Friedel-Crafts acylation hampered the synthesis of a

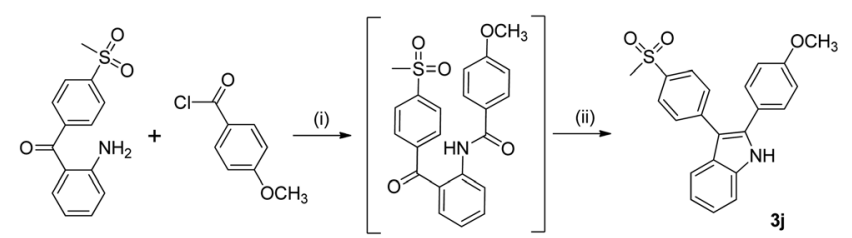

Scheme 5 Synthesis of compound $3 \mathrm{j}$ by McMurry cyclization. Reagents and conditions: (i) $\mathrm{NEt}_{3}, \mathrm{THF}$, rt, (ii) $\mathrm{TiCl}_{4}, \mathrm{Zn}, \mathrm{THF}, 65^{\circ} \mathrm{C}$.

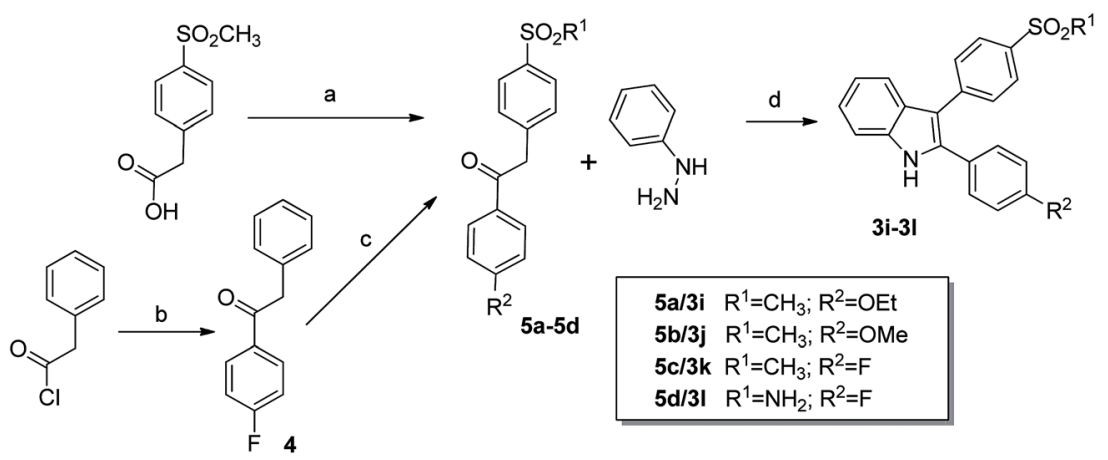

Scheme 4 Synthesis of 3-sulfonyl-substituted indoles $3 i-3 l$ by Fischer indole synthesis. Reagents and conditions: (a) for $5 \mathrm{a}-5 \mathrm{c}$ : (i) $\mathrm{SOCl}$, (ii) $\mathrm{R}^{2} \mathrm{C}_{6} \mathrm{H}_{5}, \mathrm{AlCl}_{3}, 15-20^{\circ} \mathrm{C}$; (b) $\mathrm{AlCl}_{3}$, fluorobenzene, $\mathrm{DCM}$, rt; (c) for $5 \mathrm{~d}$ : (i) $\mathrm{ClSO}_{3} \mathrm{H}$, (ii) $\mathrm{NH}_{3}$ (aq.), ethyl acetate, $\mathrm{rt}$; (d) $\mathrm{BF}_{3} \cdot \mathrm{Et}_{2} \mathrm{O}, \mathrm{CH}_{3} \mathrm{COOH}, 130{ }^{\circ} \mathrm{C}$. 


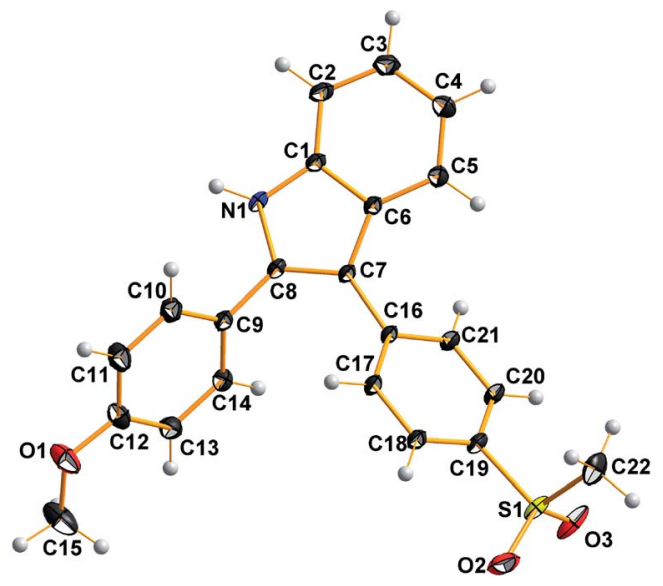

Fig. 2 Molecular Structure of compound 3j in the crystal (ORTEP plot: displacement thermal ellipsoids are drawn at 50\% probability level).

corresponding 5-methoxy-substituted indole $3 \mathrm{~m}$ via the McMurry-cyclization pathway. Thus, we decided to utilize another type of ring closure reaction, the Bischler-Möhlau cyclization for the synthesis of the methoxy-substituted derivative 3m (Scheme 6). The Bischler-Möhlau cyclisation has been used for the reaction of various methoxy-substituted anilines with 2-bromo-ketone derivatives. ${ }^{40,41}$ In our case, 1-(4-fluorophenyl)-2-sulfonylphenyl ethanone (5c) was brominated to give the precursor $5 \mathrm{e}$ in $52 \%$ yield. ${ }^{42}$ Then $5 \mathrm{e}$ was allowed to react with $p$-anisidine at $170^{\circ} \mathrm{C}$ in ethanol under pressure to form $3 \mathrm{~m}$ in $37 \%$ yield. The regioselectivity of the Bischler-Möhlau reaction is hardly predictable, so the corresponding two isomers with opposite substituent position could be formed (Scheme 6). Actually, during the workup a set of by-products was observed. However, we isolated one main product for its identification NOESY experiments were performed. Finally by the help of this technique the molecular structure of the 2-[4-(methylsulfonyl)phenyl]-3-(4-fluorophenyl)-5-methoxy- $1 H$-indole $\quad(3 \mathbf{m}) \quad$ was confirmed (Fig. 3, NOESY spectra are included in the ESI:).

\section{Optical properties}

Optical properties have been previously reported for 2,3diphenyl-1 $H$-indoles and some derivatives were found to be highly fluorescent with emission maxima in the range of 410$475 \mathrm{~nm}^{43-47}$ We recently presented the visualization of

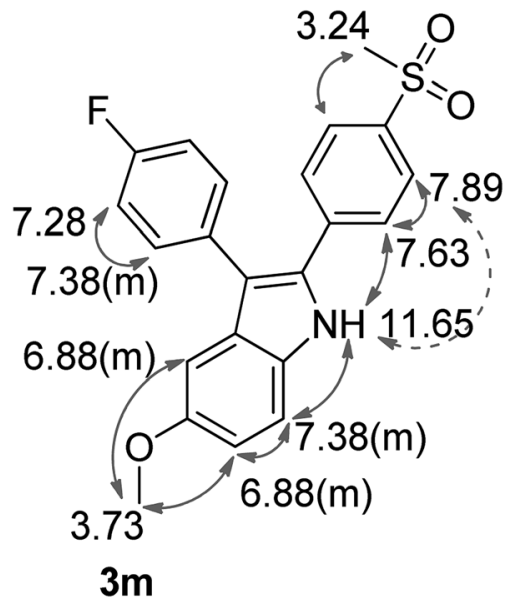

Fig. 3 The chemical shifts of $3 \mathrm{~m}$ in ${ }^{1} \mathrm{H}-\mathrm{NMR}$ (DMSO- $d_{6}, 400 \mathrm{MHz}$ ). The arrows (grey) indicate NOESY cross peaks.

cyclooxygenase-2 by confocal laser induced cryofluorescence microscopy in human melanoma cells using the fluorescent indole 3g. ${ }^{17}$ With this in mind and because one of the COX assays used by us is based on the detection of a fluorescent dye with an excitation wavelength of $530-540 \mathrm{~nm}$, we initially evaluated the optical properties of the compounds $\mathbf{3 a}-\mathbf{3 m}$. For that purpose, the UV-vis absorbance and fluorescence excitation as well as emission spectra were recorded (Table 1). Fig. 4 shows the normalized fluorescence excitation and emission spectra of compounds $\mathbf{3} \mathbf{j}$ and $\mathbf{3 m}$ as examples for the indole based COX-2 inhibitors. In summary, all indoles are characterized by an excitation maxima at $\lambda>300 \mathrm{~nm}$, a large stokes shift of 106-160 $\mathrm{nm}$ and a fluorescence emission maxima in the range of 444$492 \mathrm{~nm}$. In comparison to $3 \mathrm{~g}$ which was already used to visualize COX-2 in vitro, all tested indoles showed very similar fluorescence excitation and emission spectra so that they might be used for similar applications. Of note, 2-(4-sulfonylphenyl)substituted indoles like $\mathbf{3 m}$ have an excitation maximum between 338-354 nm whereas 3-(4-sulfonylphenyl)-substituted indoles like $3 \mathbf{j}$ showed two bands with nearly similar intensity at 300-304 $\mathrm{nm}$ and 329-334 nm. As observed by X-ray crystallography for $\mathbf{3} \mathbf{a}$ and $\mathbf{3} \mathbf{j}$, this also indicates that the interaction of the phenyl rings with the indole core differs substantially in dependence of the position of the sulfonyl moiety. Finally, no fluorescence signal is observed by excitation at $530 \mathrm{~nm}$ allowing
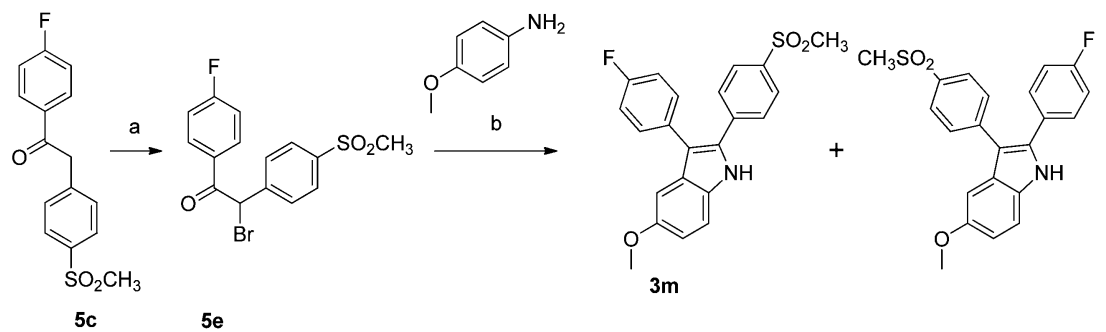

Scheme 6 Synthesis of $3 \mathrm{~m}$ by Bischler-Möhlau cyclization. Reagents and conditions: (a) $\mathrm{Br}_{2}$, benzoyl peroxide $(\mathrm{cat}), \mathrm{CCl}_{4} / \mathrm{CHCl}_{3}, 78{ }^{\circ} \mathrm{C}$; (b) $\mathrm{EtOH}, 170{ }^{\circ} \mathrm{C}$. 


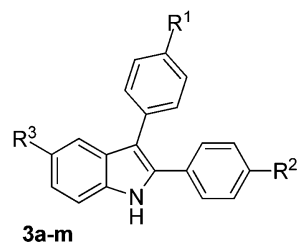

Absorption $\lambda_{\text {abs }}$ $[\mathrm{nm}]\left(\varepsilon\left[10^{4} \mathrm{M}^{-1} \mathrm{~cm}^{-1}\right]\right)$
Excitation maximum $\lambda_{\text {exc }}[\mathrm{nm}]$
Emission maximum $\lambda_{\mathrm{em}}[\mathrm{nm}]$

\begin{tabular}{|c|c|c|c|c|c|c|}
\hline & $\mathrm{R}^{1}$ & $\mathrm{R}^{2}$ & $\mathrm{R}^{3}$ & & & \\
\hline $3 \mathbf{a}$ & $\mathrm{F}$ & $\mathrm{SO}_{2} \mathrm{CH}_{3}$ & $\mathrm{H}$ & 236 (2.24), 249 (2.03), 336 (1.61) & 343 & 454 \\
\hline $3 \mathbf{b}$ & $\mathrm{F}$ & $\mathrm{SO}_{2} \mathrm{NH}_{2}$ & $\mathrm{H}$ & $253(2.08), 328(1.70)$ & 338 & 450 \\
\hline $3 \mathrm{c}$ & $\mathrm{F}$ & $\mathrm{SO}_{2} \mathrm{CH}_{3}$ & $\mathrm{CH}_{3}$ & 239 (5.62), 339 (2.03) & 345 & 475 \\
\hline 3d & $\mathrm{F}$ & $\mathrm{SO}_{2} \mathrm{NH}_{2}$ & $\mathrm{CH}_{3}$ & $238(4.06), 333(2.10)$ & 339 & 451 \\
\hline $3 \mathbf{e}$ & $\mathrm{F}$ & $\mathrm{SO}_{2} \mathrm{NH}_{2}$ & $\mathrm{OH}$ & 236 (4.33), $341(2.05)$ & 345 & 481 \\
\hline $3 f$ & $\mathrm{OCH}_{3}$ & $\mathrm{SO}_{2} \mathrm{CH}_{3}$ & $\mathrm{H}$ & 237 (2.87), 256 (2.54), 332 (1.60) & 354 & 492 \\
\hline $3 g$ & $\mathrm{OCH}_{3}$ & $\mathrm{SO}_{2} \mathrm{NH}_{2}$ & $\mathrm{H}$ & 237 (3.71), 325 (1.61) & 345 & 482 \\
\hline $3 \mathbf{h}$ & $\mathrm{OCH}_{3}$ & $\mathrm{SO}_{2} \mathrm{NHAc}$ & $\mathrm{H}$ & $256(2.98), 323(1.80)$ & 339 & 452 \\
\hline $3 \mathbf{i}$ & $\mathrm{SO}_{2} \mathrm{CH}_{3}$ & $\mathrm{OCH}_{2} \mathrm{CH}_{3}$ & $\mathrm{H}$ & 238 (1.97), 300 (1.73), 340sh (0.93) & 303 & 451 \\
\hline $3 \mathbf{j}$ & $\mathrm{SO}_{2} \mathrm{CH}_{3}$ & $\mathrm{OCH}_{3}$ & $\mathrm{H}$ & 238 (3.18), 300 (2.35), 344 (1.23) & 344 & 450 \\
\hline $3 \mathbf{k}$ & $\mathrm{SO}_{2} \mathrm{CH}_{3}$ & $\mathrm{~F}$ & $\mathrm{H}$ & 238 (4.47), 296 (2.17), 337 (1.27) & 300 & 444 \\
\hline 31 & $\mathrm{SO}_{2} \mathrm{NH}_{2}$ & $\mathrm{~F}$ & $\mathrm{H}$ & 237 (3.85), 296 (2.06), 329sh (1.36) & 303 & 443 \\
\hline $3 \mathrm{~m}$ & $\mathrm{~F}$ & $\mathrm{SO}_{2} \mathrm{CH}_{3}$ & $\mathrm{OCH}_{3}$ & $237(4.52), 344(2.54)$ & 349 & 484 \\
\hline
\end{tabular}

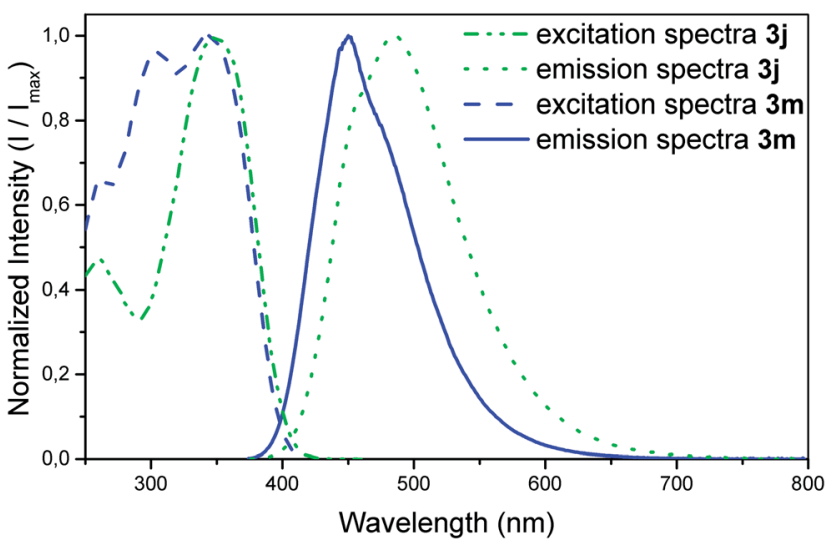

Fig. 4 Fluorescence excitation and emission spectra of compound 3j and $3 \mathrm{~m}$. Emission spectra were acquired with an excitation wavelength of $344 \mathrm{~nm}$ and $349 \mathrm{~nm}$ for $3 \mathrm{j}$ and $3 \mathrm{~m}$, respectively.

the determination of COX-inhibitory activity with the fluorescence-based COX assay.

\section{Biological evaluation}

Fluorescence-based COX-assay. The in vitro COX inhibitory activity of the indoles $\mathbf{3 a}-\mathbf{3} \mathbf{m}$ and celecoxib as a reference was evaluated with a fluorescence-based COX assay ("COX Fluorescent Inhibitor Screening Assay Kit”, Item no. 700100, Cayman Chemical, Ann Arbor, USA) that utilizes the COX-mediated reduction of $\mathrm{PGG}_{2}$ to $\mathrm{PGH}_{2}$ to oxidize 10-acetyl-3,7-dihydroxyphenoxazine to resorufin. This highly fluorescent compound can easily be analyzed with an excitation wavelength of 530$540 \mathrm{~nm}$ and emission wavelength of $585-595 \mathrm{~nm}$. The results of the COX inhibitory activity of the 2,3-diaryl-substituted indoles $\mathbf{3 a}-\mathbf{3 m}$ from this fluorescence-based COX-assay are summarized at the left part of Table 2. In all determinations celecoxib was used as internal standard and for COX-1/COX-2 selectivity giving at least no difference between our results and literature data.

Generally we found that all synthesized 2,3-diarylsubstituted indoles are inhibitors of COX-2 in the low micromolar or sub-micromolar level. This is in accordance with previous literature findings from other groups describing $\mathbf{3 a}$, $\mathbf{3 b}, \mathbf{3 f}, \mathbf{3 g}$ and $\mathbf{3 k}$ as selective COX-2-inhibitors. ${ }^{9,10,48}$ The results from the assay used by us, showed that in $1 \mu \mathrm{M}$ concentration $3 \mathbf{a}, 3 \mathbf{b}, 3 \mathbf{e}, 3 \mathbf{g}, 3 \mathbf{i}, 3 \mathbf{j}$ did inhibit more than $50 \%$ of COX-2 activity and four derivatives $(\mathbf{3 e}, \mathbf{3 f}, \mathbf{3 g}, \mathbf{3 m})$ inhibited even better, between $30-40 \%$ in the $0.1 \mu \mathrm{M}$ level. With view on regioisomers it is difficult to predict any significant impact from the position of the methylsulfonyl or the aminosulfonyl group to COX-2 affinity. For the regioisomers 3a/3k a higher activity is observed with the methylsulfone on the 2-phenyl ring, but for the pair $\mathbf{3 b}$ / 31 values in the same range were found. Furthermore, there is no clear tendency if the methylsulfone substituent is superior to the sulfonamide because by direct comparison of two derivatives having the identical core but different sulfonyl substituents similar activities to COX-2 were found as demonstrated by the pairs $\mathbf{3 a} / \mathbf{3 b}, \mathbf{3} \mathbf{c} / \mathbf{3 d}$ and $\mathbf{3 f} / \mathbf{3 g}$. Compounds with a fluorinesubstituent generally show a lower inhibition of COX-2 because in all investigated compounds its replacement by a methoxy group lead to increased inhibition as has been demonstrated for the cases $\mathbf{3 a} / \mathbf{3 f}, \mathbf{3 b} \mathbf{3} \mathbf{3 g}$, and $\mathbf{3} \mathbf{k} / \mathbf{3} \mathbf{j}$. Acetylation of the sulfonamide resulted likewise in loss of activity as visible in $\mathbf{3 g}$ versus $3 \mathbf{h}$, a similar reduction is observed by replacement of a methoxy by an ethoxy group ( $3 \mathbf{i}$ versus $3 \mathbf{j}$ ). Notable is the impact of the substituent in 5-position of the indole system $\left(\mathrm{R}^{3}\right)$ on the COX-2 inhibitory activity. By direct comparison of a hydrogen (3a), a methyl- (3c) and a methoxy-group (3m) the latter gives the best inhibition to COX-2 whereas the methyl substituent lead to 
Table 2 COX-inhibitory and antioxidant properties of 2,3-diphenyl-1H-indole derivatives $3 a-3 m^{a}$

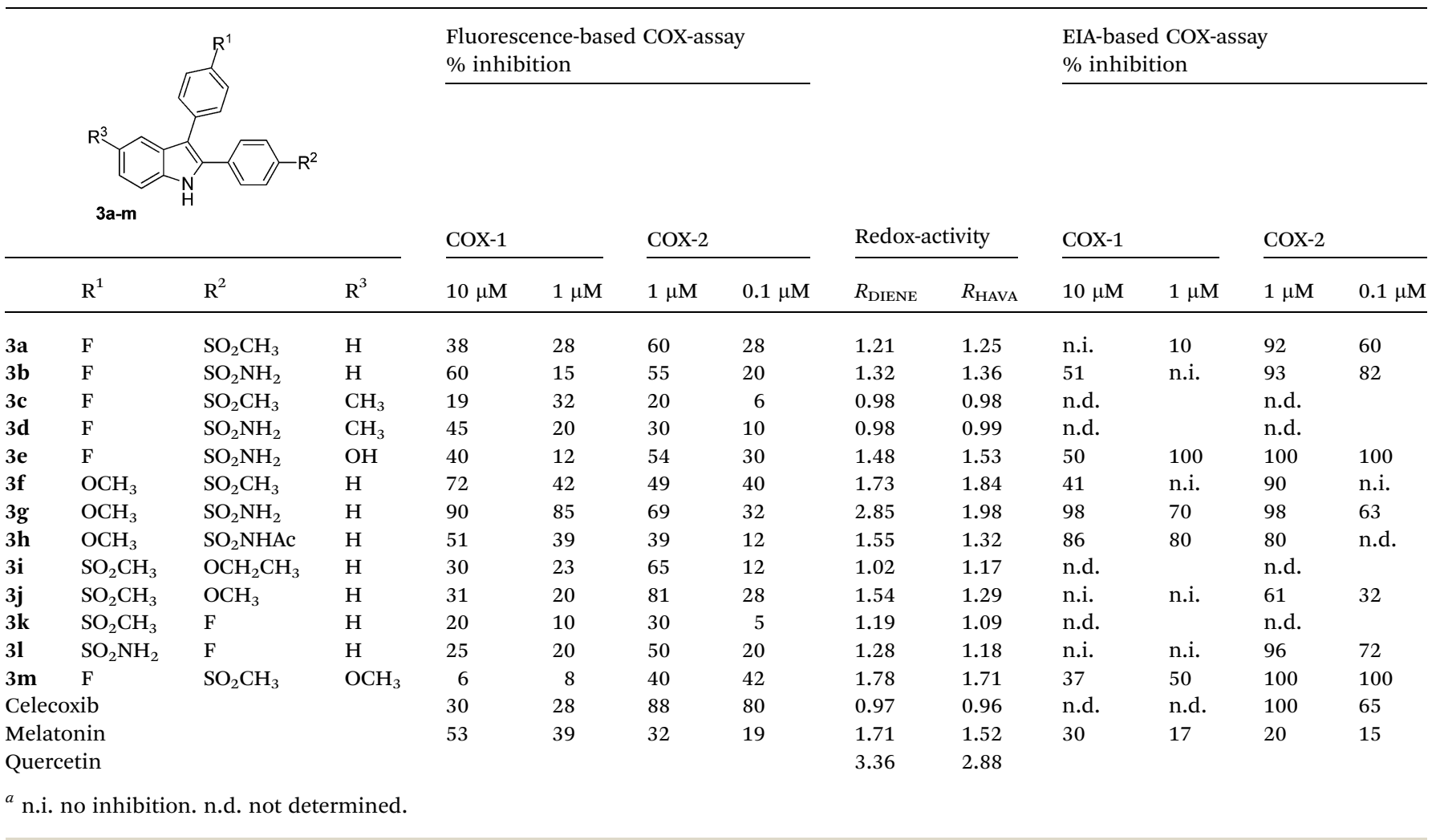

decreased affinity. Even a hydroxyl group at this position is well tolerated (3e) and results in $40 \%$ inhibition at $0.1 \mu \mathrm{M}$ level.

In summary in the series of thirteen 2,3-diaryl substituted indoles the COX-2 inhibitory activity of the known compounds was confirmed and, compared to $\mathbf{3 a}$, three even more potent derivatives, $\mathbf{3 e}, \mathbf{3 g}$ and $\mathbf{3 m}$ could be identified.

Furthermore, we determined the inhibition profile of all compounds to COX-1 and found that most of the derivatives lacked COX-1 inhibitory activity as expected. However the methoxy-substituted compounds $\mathbf{3 f}-\mathbf{3 g}$ attracted our attention because $\mathbf{3 f}-\mathbf{3 g}$ appeared to be moderate inhibitors of COX-1, and especially $\mathbf{3 g}$ was even a more potent COX-1 than COX-2 inhibitor. The last finding was in harsh contrast to the literature, and we suspected false positive results since the fluorescence-based COX-assay is influenced by antioxidants as noted by the manufacturer. Particularly, the indole heterocycle is a wellcharacterized antioxidant pharmacophore ${ }^{\mathbf{4 9 , 5 0}}$ and it had to be considered that possibly antioxidative properties of $\mathbf{3 a - 3 m}$ interfered with the assay and caused these deviations. This hypothesis was supported by our first findings in parallel in vitro experiments that indole $\mathbf{3 g}$ was able to inhibit not only the formation of $\mathrm{PGE}_{2}$ but also the formation of 8-iso- $\mathrm{PGF}_{2 \alpha}$ generated via non-enzymatic oxidation after the exposure of endothelial cells in both monolayer and organo-type aortic ring models to ionizing radiation. ${ }^{51,52}$ Thus, we decided to evaluate the antioxidant capacity of the indole based COX-2 inhibitors 3a-3m.

Redox activity-structure relationships. The antioxidant potency of the COX-inhibitors was investigated using a lowdensity lipoprotein (LDL) copper-/iron-peroxidation model. The results are shown in the middle part of Table 2 . The redox activity is expressed as $R_{\mathrm{DIENE}}$ and $R_{\mathrm{HAVA}}$ ratios indicating effects of the compounds tested on either lipid oxidation or protein oxidation. In both approaches $R$ values $\left(R_{\text {DIENE }}\right.$ or $\left.R_{\text {HAVA }}\right)$ higher than 1 indicate antioxidant activity while a $R$ value of about 1 stands for no effect. For comparison, celecoxib, the indole hormone melatonin, and the polyphenol quercetin were studied. As expected, celecoxib did not exhibit any redox activity in the model systems used. In contrast, both quercetin and melatonin showed a substantial antioxidative activity both on lipid and protein oxidation. Interestingly, all tested compounds with an unsubstituted 5-position in the indole heterocycle $\left(\mathrm{R}^{3}=\right.$ $\mathrm{H})$ showed a significant antioxidative action that was mostly comparable to melatonin. Noteworthy, compound $\mathbf{3 g}$ showed the highest antioxidative potential which was significantly higher than that of melatonin but less active than quercetin. This antioxidative action of indole compounds is hypothesized to follow a mechanism discussed in detail for other indole antioxidants like 2-phenylindoles. ${ }^{53}$ The proposed mechanism essentially would allow the presence of substituents like a methoxy group or a hydroxyl group at 5-position. Gozzo et al. demonstrated that the presence of 5-methoxy or 5-hydroxyl groups in melatonin analogues induces beneficial effects on their antioxidative activity. ${ }^{54}$ In the present study the introduction of a methoxy or a hydroxyl group at position 5 also resulted in higher antioxidant activity as is demonstrated for $\mathbf{3 e} / \mathbf{3 b}$ as well as $\mathbf{3 m} / \mathbf{3 a}$, respectively. In contrast, the introduction of a methyl group at position 5 substantially attenuates antioxidant activity as demonstrated for $\mathbf{3 c / 3} \mathbf{3}$ and $\mathbf{3 d} / \mathbf{3 b}$. These data further 
support the suggested mechanism. Furthermore, a beneficial effect also could be observed when methoxy groups were introduced in para-position of 2- or 3-phenyl rings $(3 \mathbf{f} / \mathbf{3 a} ; \mathbf{3 g} / \mathbf{3 b})$. Overall, the presence of methoxy groups favored antioxidant potential of indole derivatives with a slightly higher antioxidant activity for methoxy in para-position of the 3-phenyl ring compared to para-position of the 2-phenyl ring $(\mathbf{3 f} / 3 \mathbf{j})$. Of interest, the sulfonamide moiety increases the antioxidant activity when compared with the methylsulfone as demonstrated for $\mathbf{3 b} / \mathbf{3 a}, \mathbf{3} \mathbf{g} / \mathbf{3 f}$, and $\mathbf{3 l} / \mathbf{3} \mathbf{k}$. This tendency also was observed in a study of Walter and colleagues who reported prooxidative effects related to the sulfone agents rofecoxib and etoricoxib, respectively, compared to redox-neutral effects of sulfonamides celecoxib and valdecoxib. ${ }^{55}$ Regarding protein oxidation the relationship between antioxidative capacity and different substituents in indole compounds are consistent with those observed for lipid oxidation.

EIA-based COX-assay. Hence, some of the indoles exhibited substantial antioxidative properties and in order to avoid false positive results issued from the fluorescence-based COX-assay we decided to subject selected compounds (3a, 3b, $\mathbf{3 e -} \mathbf{3 h}, \mathbf{3 m}$ ) regarding their COX inhibitory activity to a second assay. For that purpose we chose an enzyme immunoassay (EIA) based COX assay ("COX Inhibitor Screening Assay Kit", Item no. 560131, Cayman Chemical, Ann Arbor, USA). Since this assay is determining the COX-activity via EIA based detection of prostaglandins and not via a redox-coupled mechanism, it seemed promising to eliminate the false positive results from our experiments. The results are displayed in the right part of Table 2. On a first look at the compound with the highest antioxidative potential 3g, it turned out that this substance is, although not very selective, a slightly better COX-2 than COX-1 inhibitor with $98 \%$ compared to $70 \%$ inhibition at the $1 \mu \mathrm{M}$ level, respectively. A similar result was found for $\mathbf{3 f}$ which showed in the fluorescence-based assay only moderate selectivity to COX-2 but in the enzyme immunoassay-based COX-assay no inhibition of COX-1 and $90 \%$ inhibition of COX- 2 at the $1 \mu \mathrm{M}$ level. These findings support the hypothesis that the results of the fluorescencebased assay for 2,3-diaryl-substituted indoles concerning COX-2 are affected by their redox activity. In contrast, for compounds $\mathbf{3 e}, \mathbf{3 j}$ and $\mathbf{3 m}$ that were already found to be COX-2 selective with the fluorescence-based assay, no such tendency was observed although these compounds had comparable $R$ values with $3 \mathbf{f}$. In an additional experiment we subjected melatonin that is also a 5-methoxy-substituted indole derivative and an antioxidant to both COX assays. As a result we found only a weak inhibition of both enzymes by melatonin with a slightly higher activity but comparable selectivity in the fluorescence-based assay. These finding let us conclude that the redox activity at this level ( $R_{\text {DIENE }}$ and $R_{\text {HAVA }}$ value about 1.7 ) has only minor effect on the result of the assays. Consistently, for compounds having a $R_{\text {DIENE }}$ and $R_{\text {HAVA }}$ value of about 1.3 , that means only slightly redox active compounds $(\mathbf{3 a}, \mathbf{3 b}, \mathbf{3} \mathbf{l})$, the inhibitory activity to COX-1 and COX-2 is more or less comparable for both assays.

As in the fluorescence-based assay, no clear tendency for the regioisomers was found since the regioisomers $3 \mathbf{a} / 3 \mathbf{k}$ as well as 3f/3j showed similar COX-2/COX-1 selectivity although $3 \mathbf{f}$ seems slightly more potent than $\mathbf{3 j}$. A similar statement can be made for the position of the aminosulfonyl and methylsulfonyl substituents because $\mathbf{3 a} / \mathbf{3} \mathbf{b}$ were both highly selective inhibitors of COX-2 and within the pair $\mathbf{3 f} / \mathbf{3 g}$ only $\mathbf{3 f}$ was a selective COX-2 inhibitor. In contrast to the fluorescence-based assay, also no clear tendency was observed for the comparison of fluorine with methoxy substituted compounds since in both groups very selective as well as unselective inhibitors were found.

\section{Conclusions}

The objective of this work was to develop and characterize in detail a series of 2,3-diaryl-substituted indoles selectively inhibiting cyclooxygenase-2, and preferably bearing a fluorine or methoxy-substituent, in order to gain a pool of versatile compounds promising for ${ }^{18} \mathrm{~F}$ - or ${ }^{11} \mathrm{C}$-PET radiotracer development. The position of the fluoro and methoxy group - on the 2aryl respectively on the 3-aryl substituent - and of the appropriate methylsulfonyl or aminosulfonyl moiety should be altered with view on the resulting affinity towards COX-1 and COX-2.

For that purpose thirteen derivatives of 2,3-diaryl-substituted indoles have been synthesized by applying different ring closure reactions, as Fischer-indole synthesis, McMurry cyclization or Bischler-Möhlau cyclization. Among them the McMurry cyclization proofed to be an excellent approach due to its regioselectivity, modularity and the good yields that were obtained. The spectroscopic and fluorescent properties of all 2,3-diarylsubstituted indoles revealed that all the compounds are fluorescent with emission maxima acceptable for biological investigations in vitro and partly in vivo.

To determine the COX inhibition activity two separate in vitro assays, one fluorescence-based and one enzyme immunoassay-based, were used. This exceptional approach was essential because it is known that each individual assay can have its limitations regarding the chemical and physical properties of the subjected compounds. In our case we found that the indoles do not only show fluorescence, some of them possess a considerable redox activity which is known to interact with the fluorescence-based assay, and as a consequence false results may be occur. Indeed, for $\mathbf{3} \mathbf{g}$ that showed the highest redox activity $\left(R_{\mathrm{DIENE}}=2.85, R_{\mathrm{HAVA}}=1.98\right)$ of the tested indoles and appeared in the fluorescence-based assay as a more potent COX-1 than COX-2 inhibitor, the immunoassay-based determination revealed that this compound was slightly more affine towards COX-2.

Summarizing the in vitro behavior of all 2,3-diarylsubstituted indoles it can be stated that all compounds are inhibiting COX-2, but with a slight gradation. Some of them turned out to be unselective COX inhibitors in one $(\mathbf{3 e}, \mathbf{3 f})$ respectively both $(\mathbf{3 g}, \mathbf{3 h})$ of the assays and are hence unsuitable candidates for radiotracer development. Surprisingly the introduction of a methyl-substituent to the 5-position of the indole lead to a remarkable loss of activity, hence the derivatives 3c and 3d have to be excluded as well. Since a high selectivity for COX-2 is an important criterion for potential radiotracers, 3a, $\mathbf{3 b}, \mathbf{3 j}, \mathbf{3 l}$ and $\mathbf{3 m}$ emerged as most promising candidates in the 
following order of increasing inhibitory activity based on $0.1 \mu \mathrm{M}$ concentrations: $\mathbf{3 b} \leq \mathbf{3 l}<\mathbf{3 a} \leq \mathbf{3} \mathbf{j}<\mathbf{3 m}$.

The radiolabeled COX-2 inhibitor $\left[{ }^{18} \mathrm{~F}\right] 3$ a corresponding to the non-radioactive compound $\mathbf{3 a}$ has been recently evaluated by ourselves and showed no substantial tumor accumulation, due to fast elimination and insufficient affinity to COX-2. ${ }^{30}$ The COX-2 inhibitors $\mathbf{3 b}$ and $\mathbf{3 l}$ both have a fluoro-substituent making them to suitable candidates for radiotracer development with fluorine-18. However, they possess an aminosulfonyl group that is known to interact in vivo with carbonic anhydrases in the erythrocytes, resulting in a slow blood clearance. This was demonstrated for ${ }^{125}$ I-radiolabeled celecoxib derivatives ${ }^{56}$ and should be kept in mind for the development of a ${ }^{18} \mathrm{~F}$-radiolabeled analogue of $\mathbf{3 b}$ and $\mathbf{3} \mathbf{3}$. The derivative $\mathbf{3} \mathbf{j}$ does not contain a fluorine substituent. Hence, radiolabeling with carbon-11 could be a possible approach as demonstrated by Tanaka et al. ${ }^{57}$ but the low metabolic stability of the methoxy group in vivo is always limiting the radiotracer application.

Finally, 3m turned out as the most promising candidate for radiotracer development since this compound was potent and COX-2 selective in both assays showing furthermore in the EIAbased method a complete inhibition of COX-2 in the $0.1 \mu \mathrm{M}$ level. The radiolabeling of $\mathbf{3 m}$ with fluorine-18 can be performed by using the McMurry cyclization ${ }^{30}$ as has been demonstrated for $\left[{ }^{18} \mathrm{~F}\right] \mathbf{3 a}$ because the Bischler-Möhlau reaction as labeling strategy seems to be ineffective for the introduction of the radioisotope.

\section{Experimental protocols}

All commercial reagents and solvents were used without further purification unless otherwise specified. Flash chromatography was conducted using MERCK Silica Gel (mesh size 40-63 $\mu \mathrm{m}$ ) and RP-18 silica gel (Lichroprep RP-18, 25-40 $\mu \mathrm{m}$ ). Thin-layer chromatography (TLC) was performed on Merck silica gel F-254 aluminum plates and Alugram RP-18W/ $\mathrm{UV}_{254}$. Visualization was carried out using UV (254 nm/366 nm). Analytical HPLC analysis were carried out with a Luna C18 column $(250 \times$ $4.6 \mathrm{~mm}, 5 \mu \mathrm{m}$, Phenomenex) using an isocratic eluent (acetonitrile/water $+0.1 \%$ TFA $70 / 30$ ) by a gradient pump L2500 (Merck, Hitachi) with a flow rate of $1 \mathrm{~mL} \mathrm{~min}^{-1}$. The products were monitored by an UV detector L4500 (Merck, Hitachi) at 254 $\mathrm{nm}$. All final compounds displayed $\geq 95 \%$ purity as determined by analytical HPLC. Mass spectra were obtained on a Quattro/ LC mass spectrometer (MICROMASS) by electrospray ionization. Melting points were determined on a Galen III (Cambridge Instruments) melting points apparatus (Leica, Vienna, Austria) and are uncorrected. Nuclear magnetic resonance spectra were recorded on a Varian Inova-400. NMR spectra were referenced to the residual solvent shifts for ${ }^{1} \mathrm{H}$ and ${ }^{13} \mathrm{C}$, and to $\mathrm{CFCl}_{3}$ for ${ }^{19} \mathrm{~F}$ spectra as internal standard. For some compounds, isotope effects on ${ }^{13} \mathrm{C}$ NMR chemical shifts ${ }^{58}$ were observed in acetone- $d_{6}$ which were caused by hydrogen/deuterium exchange while measurement. The signals with deuterium isotope shifts are indicated and the range from minimal to maximal value is given.
Spectroscopic and fluorescent properties were determined at the "Synergy 4 Hybrid Multi-Mode Microplate Reader" from BioTek Company. The samples were dissolved in an appropriate amount of DMSO to give a $10 \mathrm{mM}$ stock solution. To $20 \mu \mathrm{L}$ of this stock solution was added $80 \mu \mathrm{L}$ DMSO, $100 \mu \mathrm{L}$ TWEEN 20 and $9800 \mu \mathrm{L}$ PBS to yield a $20 \mu \mathrm{M}$ test solution for the measurement of the extinction coefficient. Using BioCell $1 \mathrm{~cm}$ Quartz Vessels from BioTec Company, the extinction coefficients were determined from the absorption spectra. All extinction coefficients are given in $\varepsilon / \mathrm{dm}^{3} \mathrm{~mol}^{-1} \mathrm{~cm}^{-1}$ at the specified wavelength in $\mathrm{nm}$. The fluorescence excitation and emission spectra were determined using a $100 \mu \mathrm{M}$ solution of the test compound in a solution of $1 \%$ DMSO and 1\% TWEEN 20 in PBS. In both experiments, baseline correction was done using a solution of 1\% DMSO and 1\% TWEEN 20 in PBS.

\section{Syntheses}

2-Amino-4'-fluorobenzophenone (1a). Synthesis and characterization of compound $\mathbf{1 a}$ was recently reported. ${ }^{39}$ The compound was used as starting material for the following steps.

2-Amino-4'-fluoro-5-methylbenzophenone (1b). Synthesis and characterization of compound $\mathbf{1 b}$ was recently reported. ${ }^{39}$ The compound was used as starting material for the following steps.

2-Amino-4'-fluoro-5-hydroxybenzophenone (1c). Reaction was carried out under Schlenk-conditions. Under nitrogen atmosphere, $p$-anisidine $(1.982 \mathrm{~g}, 16.1 \mathrm{mmol})$ and a solution of 4-fluorobenzonitrile (2.918 g, $24.1 \mathrm{mmol})$ in toluene $(18 \mathrm{~mL})$ was added at $0{ }^{\circ} \mathrm{C}$ to $1 \mathrm{M}$ boron trichloride in toluene $(18 \mathrm{~mL}$, $18 \mathrm{mmol}$ ). Then freshly sublimated anhydrous aluminum chloride $(2.43 \mathrm{~g}, 18.2 \mathrm{mmol}$ ) was added and the mixture was heated to reflux for $12 \mathrm{~h}$. Afterwards, the mixture was cooled to $0{ }^{\circ} \mathrm{C}$, water $(1 \mathrm{~mL})$ and $10 \% \mathrm{HCl}(18 \mathrm{~mL})$ were slowly added and the mixture was heated to reflux for $2 \mathrm{~h}$ again. The raw product was isolated by vacuum filtration after cooling the solution to $0{ }^{\circ} \mathrm{C}$. To the raw material was added water $(10 \mathrm{~mL})$ and a small amount of $\mathrm{NaHCO}_{3}$ and this mixture was extracted with ethyl acetate $(3 \times 50 \mathrm{~mL})$. The organic phases were combined, washed with saturated $\mathrm{NaHCO}_{3}(10 \mathrm{~mL})$ and water $(2 \times 10 \mathrm{~mL})$ and dried over $\mathrm{Na}_{2} \mathrm{SO}_{4}$. The crude, dried product was purified by dry column vacuum chromatography (DCVC, petroleum etherethyl acetate $90: 10 \rightarrow 50: 50)$. Compound $1 \mathrm{c}$ was obtained as a yellow-brown solid (854 mg, 23\%). mp 150-153 ${ }^{\circ} \mathrm{C} ; R_{\mathrm{f}} 0.51$ (petroleum ether-ethyl acetate $50: 50) ;{ }^{1} \mathrm{H}$ NMR $(400 \mathrm{MHz}$; DMSO- $\left.d_{6}\right) \delta$ ppm: $6.50\left(2 \mathrm{H}\right.$, br s, $\left.\mathrm{NH}_{2}\right), 6.68\left(1 \mathrm{H}, \mathrm{d},{ }^{4} J=2.6 \mathrm{~Hz}\right.$, $\left.\mathrm{H}_{\text {phenyl-6) }}\right), 6.74\left(1 \mathrm{H}, \mathrm{d},{ }^{3} J=8.8 \mathrm{~Hz}, \mathrm{H}_{\text {phenyl- } 3}\right), 6.86\left(1 \mathrm{H}, \mathrm{dd},{ }^{3} J=\right.$ $\left.8.8 \mathrm{~Hz},{ }^{4} J=2.7 \mathrm{~Hz}, \mathrm{H}_{\text {phenyl- } 4}\right), 7.34\left(2 \mathrm{H}, \mathrm{t},{ }^{3} J=8.8 \mathrm{~Hz}, \mathrm{H}_{\mathrm{F}-\text { phenyl- } 3^{\prime} / 5^{\prime}}\right)$, $7.64\left(2 \mathrm{H}, \mathrm{dd},{ }^{3} J=8.8 \mathrm{~Hz},{ }^{4} J=5.7 \mathrm{~Hz}, \mathrm{H}_{\mathrm{F}-\text { phenyl- } 2^{\prime} / 6^{\prime}}\right), 8.65(1 \mathrm{H}, \mathrm{s}$, $\mathrm{OH}) ;{ }^{13} \mathrm{C}$ NMR (101 MHz; DMSO- $\left.d_{6}\right) \delta$ ppm: $115.2\left(\mathrm{~d},{ }^{2} J=22 \mathrm{~Hz}\right)$, 116.5, 117.2, 118.2, 124.0, $131.2\left(\mathrm{~d},{ }^{3} \mathrm{~J}=9 \mathrm{~Hz}\right), 136.5$ (d, $\left.{ }^{4} \mathrm{~J}=3 \mathrm{~Hz}\right)$, 145.3, 146.0, 163.5 (d, $\left.{ }^{1} J=249 \mathrm{~Hz}\right), 196.1 ;{ }^{19} \mathrm{~F}$ NMR $(376 \mathrm{MHz}$; DMSO- $\left.d_{6}\right) \delta$ ppm: $-109.7 ; m / z$ ESI-MS $\left(\mathrm{ES}^{+}\right) 232[\mathrm{M}+\mathrm{H}]^{+}(100 \%)$.

2-Amino-4'-methoxybenzophenone (1d). Synthesis of 1d was carried out in analogy to a literature procedure.$^{10}$ Briefly, 2-(4methyl-phenylsulphonylamino)benzoic acid (4.38 g, $15 \mathrm{mmol}$ ) was suspended in dry anisole $(20 \mathrm{~mL})$ and $\mathrm{PCl}_{5}(5.57 \mathrm{~g}, 17.1$ 
mmol) was added at room temperature to the suspension in portions. The mixture was heated at $50{ }^{\circ} \mathrm{C}$ for $30 \mathrm{~min}$ and cooled to $0{ }^{\circ} \mathrm{C}$ by an ice-salt mixture. Anhydrous $\mathrm{AlCl}_{3}(8.7 \mathrm{~g}, 65.4$ $\mathrm{mmol}$ ) was added in portions, while the temperature was kept between $-3{ }^{\circ} \mathrm{C}$ and $5{ }^{\circ} \mathrm{C}$. The mixture was stirred for $6 \mathrm{~h}$ at $5-$ $10{ }^{\circ} \mathrm{C}$ and at room temperature overnight. After cooling at $0{ }^{\circ} \mathrm{C}$, ice-cold $1 \mathrm{M} \mathrm{HCl}(80 \mathrm{~mL})$ was added carefully and the suspension was treated with diethyl ether $(50 \mathrm{~mL})$, the aqueous phase was separated and extracted with diethyl ether once more $(2 \times$ $25 \mathrm{~mL}$ ). The white precipitate from the aqueous phase was filtered, washed with diethyl ether and dried under vacuum to give the intermediate product $N$-[2-(4-methoxybenzoyl)phenyl]4-(methyl)benzenesulfonamide $(1.82 \mathrm{~g}, 4.77 \mathrm{mmol})$ that was used as raw material for the next step. For deprotection, the intermediate $(1.32 \mathrm{~g}, 3.46 \mathrm{mmol})$ was dissolved in a mixture of perchloric acid $(70 \%, 7 \mathrm{~mL})$ and acetic acid $(2.75 \mathrm{~mL})$, heated at $100{ }^{\circ} \mathrm{C}$ and kept for $3 \mathrm{~h}$ at this temperature. After cooling, the solution was added to crushed ice $(50 \mathrm{~mL})$ and neutralized with aqueous $\mathrm{NH}_{3}(25 \%)$. The yellow precipitate was allowed to crystallize and collected by filtration to give $\mathbf{1 d}$ as yellow crystals $(0.52 \mathrm{~g}, 21 \%)$. mp $75-77{ }^{\circ} \mathrm{C}$ (lit., ${ }^{59} 75-76{ }^{\circ} \mathrm{C}$ ); $R_{\mathrm{f}} 0.57$ (petroleum ether-ethyl acetate $30: 70) ;{ }^{1} \mathrm{H}$ NMR (400 MHz; DMSO- $\left.d_{6}\right) \delta$ ppm: $3.83\left(3 \mathrm{H}, \mathrm{s}, \mathrm{OCH}_{3}\right), 6.51\left(1 \mathrm{H}, \mathrm{t},{ }^{3} J=7.4 \mathrm{~Hz}, \mathrm{H}_{\text {arom }}\right), 6.79-$ $6.86\left(3 \mathrm{H}, \mathrm{m}, \mathrm{NH}_{2} / \mathrm{H}_{\text {arom }}\right), 7.05\left(2 \mathrm{H}, \mathrm{d},{ }^{3} J 8.6 \mathrm{~Hz}, \mathrm{H}_{\text {anisole }}\right), 7.22-$ 7.32 (2H, m, $\left.\mathrm{H}_{\text {arom }}\right), 7.58\left(2 \mathrm{H}, \mathrm{d},{ }^{3} \mathrm{~J}=8.6 \mathrm{~Hz}, \mathrm{H}_{\text {anisole }}\right) ;{ }^{13} \mathrm{C}$ NMR (101 MHz; DMSO- $\left.d_{6}\right) \delta$ ppm: $55.4\left(\mathrm{CH}_{3} \mathrm{O}\right), 113.5,114.1,116.8$, 117.2, 131.3, 131.9, 133.3, 133.6, 151.3, 161.8, 196.6 (CO).

\section{General procedure A for the synthesis of $\mathrm{N}$-(2-benzoylphenyl) benzamides (2a-2g)}

Under nitrogen atmosphere, to a solution of the appropriate 2aminobenzophenone $(0.87 \mathrm{mmol})$ and $\mathrm{NEt}_{3}(138 \mu \mathrm{L})$ in THF $(1.8 \mathrm{~mL})$ was added the appropriate 4-sulfonylbenzoyl chloride $(0.87 \mathrm{mmol})$ in THF $(1.0 \mathrm{~mL})$. The mixture was stirred at room temperature for $2 \mathrm{~h}$, filtered and the solid was washed with tetrahydrofuran. The filtrate was concentrated to dryness under reduced pressure and further purified as described below.

$\mathrm{N}$-[2-(4-Fluorobenzoyl)phenyl]-4-(methylsulfonyl)benzamide (2a). Synthesis and characterization of compound 2a was recently reported..$^{30}$ Compound $2 \mathbf{a}$ was used for the following steps.

4-(Aminosulfonyl)- $\boldsymbol{N}$-[2-(4-fluorobenzoyl)phenyl]benzamide (2b). Purification of the raw product obtained by general procedure A was carried out by column chromatography (petroleum ether-ethyl acetate $50: 50$ ). Starting from 1a (258 $\mathrm{mg}, 1.20 \mathrm{mmol}$ ) and 4-sulfamoylbenzoyl chloride (262 mg, $1.20 \mathrm{mmol}$ ), 2b was obtained as pale yellow solid (300 mg, 62\%). mp 202-203 ${ }^{\circ} \mathrm{C}$ (lit., ${ }^{11} 204-206{ }^{\circ} \mathrm{C}$ ); $R_{\mathrm{f}} 0.36$ (petroleum etherethyl acetate 50/50); ${ }^{1} \mathrm{H}$ NMR (400 $\left.\mathrm{MHz} ; \mathrm{CD}_{3} \mathrm{CN}\right) \delta \mathrm{ppm}: 5.78$ $\left(2 \mathrm{H}\right.$, br s, $\left.\mathrm{SO}_{2} \mathrm{NH}_{2}\right), 7.20-7.30\left(3 \mathrm{H}, \mathrm{m},{ }^{3} \mathrm{~J}=8.9 \mathrm{~Hz},{ }^{3} \mathrm{~J}=7.9 \mathrm{~Hz}\right.$, $\left.\mathrm{H}_{\text {phenyl }}\right), 7.63\left(1 \mathrm{H}, \mathrm{dd},{ }^{3} J=7.9 \mathrm{~Hz},{ }^{4} J=1.5 \mathrm{~Hz}, \mathrm{H}_{\text {phenyl }}\right), 7.70(1 \mathrm{H}$, $\left.\mathrm{t},{ }^{3} J=7.9 \mathrm{~Hz},{ }^{4} J=1.7 \mathrm{~Hz}, \mathrm{H}_{\text {phenyl }}\right), 7.80\left(2 \mathrm{H}, \mathrm{dd},{ }^{3} J=8.9 \mathrm{~Hz},{ }^{4} J=\right.$ $\left.5.5 \mathrm{~Hz}, \mathrm{H}_{\mathrm{F}-\text { phenyl-2/6 }}\right), 8.00\left(2 \mathrm{H}, \mathrm{d},{ }^{3} J=8.6 \mathrm{~Hz}, \mathrm{H}_{\text {phenyl }}\right), 8.05(2 \mathrm{H}$, $\left.\mathrm{d},{ }^{3} J=8.8 \mathrm{~Hz}, \mathrm{H}_{\text {phenyl }}\right), 8.50\left(1 \mathrm{H}, \mathrm{dd},{ }^{3} J=8.3 \mathrm{~Hz},{ }^{4} J=0.9 \mathrm{~Hz}\right.$, $\mathrm{H}_{\text {phenyl }}$ ), 11.15 (1H, br s, NH); ${ }^{1} \mathrm{H}$ NMR (400 MHz; DMSO- $\left.d_{6}\right) \delta$ ppm: $7.30\left(2 \mathrm{H}, \mathrm{t},{ }^{3} J=8.9 \mathrm{~Hz}, \mathrm{H}_{\mathrm{F}-\text { phenyl-3/5 }}\right), 7.37\left(1 \mathrm{H}, \mathrm{t},{ }^{3} J=7.8\right.$
$\left.\mathrm{Hz},{ }^{3} J=6.8 \mathrm{~Hz},{ }^{4} J=1.8 \mathrm{~Hz}, \mathrm{H}_{\text {phenyl }}\right), 7.47-7.54\left(3 \mathrm{H}, \mathrm{m}, \mathrm{H}_{\text {phenyl }} /\right.$ $\left.\mathrm{SO}_{2} \mathrm{NH}_{2}\right), 7.63-7.71\left(2 \mathrm{H}, \mathrm{m}, \mathrm{H}_{\text {phenyl }}\right), 7.76\left(2 \mathrm{H}, \mathrm{dd},{ }^{3} J 8.8 \mathrm{~Hz},{ }^{4} J=\right.$ $\left.5.6 \mathrm{~Hz}, \mathrm{H}_{\text {F-phenyl-2/6 }}\right), 7.81\left(2 \mathrm{H}, \mathrm{d},{ }^{3} J=8.7 \mathrm{~Hz}, \mathrm{H}_{\text {phenyl }}\right), 7.88(2 \mathrm{H}$, $\left.\mathrm{d},{ }^{3} \mathrm{~J}=8.6 \mathrm{~Hz}, \mathrm{H}_{\text {phenyl }}\right), 10.75(1 \mathrm{H}$, br s, NH$) ;{ }^{13} \mathrm{C} \mathrm{NMR}(101 \mathrm{MHz}$; DMSO- $\left.d_{6}\right) \delta$ ppm: $115.3\left(\mathrm{~d},{ }^{2} J=22 \mathrm{~Hz}\right), 124.5,125.0,125.6$, 128.0, 130.1, 131.4, 132.0, 132.4 (d, $\left.{ }^{3} J=9 \mathrm{~Hz}\right), 133.8\left(\mathrm{~d},{ }^{4} J=3\right.$ $\mathrm{Hz}), 136.1,136.9,146.7,164.4,164.6\left(\mathrm{~d},{ }^{1} \mathrm{~J}=251 \mathrm{~Hz}\right), 193.8 ;{ }^{19} \mathrm{~F}$ NMR (376 MHz; DMSO- $d_{6}$ ) $\delta$ ppm: -107.2; ESI-MS $\left(\mathrm{ES}^{+}\right) \mathrm{m} / z 421$ $[\mathrm{M}+\mathrm{Na}]^{+}(100 \%), 399[\mathrm{M}+\mathrm{H}]^{+}(69), 462\left[\mathrm{M}+\mathrm{Na}+\mathrm{CH}_{3} \mathrm{CN}\right]^{+}(69)$.

$\boldsymbol{N}$-[2-(4-Fluorobenzoyl)-4-methylphenyl]-4-(methylsulfonyl)benzamide (2c). Purification of the raw product obtained by general procedure A was carried out by column chromatography (petroleum ether-ethyl acetate- $\mathrm{NEt}_{3} 65: 30: 5 \rightarrow 47.5: 47.5: 5$ ). Starting from 1 b $(315 \mathrm{mg}, 1.37 \mathrm{mmol})$ and 4-(methylsulfonyl) benzoyl chloride (300 mg, $1.37 \mathrm{mmol}$ ), 2c was obtained as pale yellow crystalline solid (540 mg, 96\%). mp $195-197{ }^{\circ} \mathrm{C} ; R_{\mathrm{f}} 0.40$ (petroleum ether-ethyl acetate $50: 50) ;{ }^{1} \mathrm{H}$ NMR $(400 \mathrm{MHz}$; acetone- $\left.d_{6}\right) \delta$ ppm: $2.36\left(3 \mathrm{H}, \mathrm{s}, \mathrm{CH}_{3}\right), 3.19\left(3 \mathrm{H}, \mathrm{s}, \mathrm{SO}_{2} \mathrm{CH}_{3}\right), 7.31$ $\left(2 \mathrm{H}, \mathrm{t},{ }^{3} \mathrm{~J}=8.8 \mathrm{~Hz}, \mathrm{H}_{\mathrm{F}-\text { phenyl-3/5 }}\right), 7.48\left(1 \mathrm{H}, \mathrm{d},{ }^{4} \mathrm{~J}=1.7 \mathrm{~Hz}, \mathrm{H}_{\text {phenyl }}\right)$, $7.54\left(1 \mathrm{H}, \mathrm{dd},{ }^{3} J=8.4 \mathrm{~Hz},{ }^{4} J=2.1 \mathrm{~Hz}, \mathrm{H}_{\text {phenyl }}\right), 7.87\left(2 \mathrm{H}, \mathrm{dd},{ }^{3} J=\right.$ $\left.8.9 \mathrm{~Hz},{ }^{4} J=5.5 \mathrm{~Hz}, \mathrm{H}_{\text {F-phenyl-2/6 }}\right), 8.12\left(2 \mathrm{H}, \mathrm{d},{ }^{3} J=8.4 \mathrm{~Hz}, \mathrm{H}_{\text {phenyl }}\right)$, $8.16\left(2 \mathrm{H}, \mathrm{d},{ }^{3} J=8.5 \mathrm{~Hz}, \mathrm{H}_{\text {phenyl }}\right), 8.44\left(1 \mathrm{H}, \mathrm{dd},{ }^{3} J=8.4 \mathrm{~Hz},{ }^{4} J=3.8\right.$ $\left.\mathrm{Hz}, \mathrm{H}_{\text {phenyl }}\right), 11.29$ (1H, br s, NH); ${ }^{13} \mathrm{C}$ NMR (101 MHz; acetone- $\left.d_{6}\right)$ $\delta$ ppm: 20.8, 44.1, 116.2 (d, $\left.{ }^{2} J=22 \mathrm{~Hz}\right), 123.0^{*}, 126.7^{*}, 128.7$, 129.0, 133.6 (d, $\left.{ }^{3} J=9 \mathrm{~Hz}\right), 133.8^{*}, 134.1^{*}, 135.2^{*}, 135.8\left(\mathrm{~d},{ }^{4} \mathrm{~J}=3\right.$ $\mathrm{Hz})^{*}, 137.9^{*}, 140.3^{*}, 145.1^{*}, 164.6^{*}, 166.1$ (d, ${ }^{1} J=252 \mathrm{~Hz}$ ), $198.1 *, *$ deuterium isotope shifts were observed in the range of 7 to $112 \mathrm{ppb} ;{ }^{19} \mathrm{~F}$ NMR (376 MHz; $\left.\mathrm{CD}_{3} \mathrm{CN}\right) \delta \mathrm{ppm}$ : -108.5; ESI-MS $\left(\mathrm{ES}^{-}\right) \mathrm{m} / \mathrm{z} 410\left([\mathrm{M}-\mathrm{H}]^{-}, 100 \%\right)$. Crystals suitable for X-ray crystallography were obtained by slow evaporation from ethyl acetate at room temperature. Detailed results of the single-crystal X-ray structure determination are given below and in the ESI.t.

4-(Aminosulfonyl)- $\mathrm{N}$-[2-(4-fluorobenzoyl)-4-methylphenyl]benzamide (2d). Purification of the raw product obtained by general procedure A was carried out by column chromatography (petroleum ether-ethyl acetate 50 : 50). Starting from 1b (204 $\mathrm{mg}, 0.89 \mathrm{mmol}$ ) and 4-sulfamoylbenzoyl chloride (194 mg, 0.89 $\mathrm{mmol}$ ), 2d was obtained as colorless crystalline solid (252 $\mathrm{mg}$, $69 \%$ ). mp 230-231 ${ }^{\circ} \mathrm{C} ; R_{\mathrm{f}} 0.40$ (petroleum ether-ethyl acetate 50 : 50); ${ }^{1} \mathrm{H}$ NMR (400 MHz; $\left.\mathrm{CD}_{3} \mathrm{CN}\right) \delta \mathrm{ppm}: 2.35\left(3 \mathrm{H}, \mathrm{s}, \mathrm{CH}_{3}\right)$, $5.77\left(2 \mathrm{H}\right.$, br s, $\left.\mathrm{SO}_{2} \mathrm{NH}_{2}\right), 7.24\left(2 \mathrm{H}, \mathrm{t},{ }^{3} \mathrm{~J}=8.9 \mathrm{~Hz}, \mathrm{H}_{\mathrm{F}-\text { phenyl-3/5}}\right)$, $7.43\left(1 \mathrm{H}, \mathrm{d},{ }^{4} J=1.6 \mathrm{~Hz}, \mathrm{H}_{\text {phenyl }}\right), 7.51\left(1 \mathrm{H}, \mathrm{dd},{ }^{3} J=8.4 \mathrm{~Hz},{ }^{4} J=\right.$ $\left.1.7 \mathrm{~Hz}, \mathrm{H}_{\text {phenyl }}\right), 7.80\left(2 \mathrm{H}, \mathrm{dd},{ }^{3} J=8.9 \mathrm{~Hz},{ }^{4} J=5.5 \mathrm{~Hz}, \mathrm{H}_{\text {F-phenyl-2/6 }}\right)$, 7.96-8.04 (4H, m, $\left.{ }^{3} J=8.7 \mathrm{~Hz}, \mathrm{H}_{\text {phenyl }}\right), 8.32\left(1 \mathrm{H}, \mathrm{d},{ }^{3} J=8.4 \mathrm{~Hz}\right.$, $\left.\mathrm{H}_{\text {phenyl }}\right), 10.91\left(1 \mathrm{H}\right.$, br s, NH); ${ }^{13} \mathrm{C} \mathrm{NMR}\left(101 \mathrm{MHz} ; \mathrm{CD}_{3} \mathrm{CN}\right) \delta \mathrm{ppm}$ : 21.4, $116.9\left(\mathrm{~d},{ }^{2} \mathrm{~J}=22 \mathrm{~Hz}\right), 123.8,127.7,128.1,129.5,134.3\left(\mathrm{~d},{ }^{3} J=\right.$ $9 \mathrm{~Hz}), 134.6,135.2,135.9,136.4$ (d, $\left.{ }^{4} \mathrm{~J}=3 \mathrm{~Hz}\right), 138.2$, 139.8, 147.7, 165.6, $166.9\left(\mathrm{~d},{ }^{1} J=237 \mathrm{~Hz}\right), 199.1 ;{ }^{19} \mathrm{~F} \mathrm{NMR}\left(376 \mathrm{MHz} ; \mathrm{CD}_{3} \mathrm{CN}\right) \delta$ ppm: -108.6; ESI-MS $\left(\mathrm{ES}^{-}\right) \mathrm{m} / \mathrm{z} 411[\mathrm{M}-\mathrm{H}]^{-}(100 \%)$.

4-(Aminosulfonyl)- $\mathrm{N}$-[2-(4-fluorobenzoyl)-4-hydroxyphenyl]benzamide (2e). Purification of the raw product obtained by general procedure A was carried out by column chromatography (petroleum ether-ethyl acetate $50: 50 \rightarrow 0: 100$ ). Starting from 1c (250 mg, $1.08 \mathrm{mmol}$ ) and 4-sulfamoylbenzoyl chloride (224 mg, $1.02 \mathrm{mmol}$ ), 2e was obtained as yellow solid (275 mg, $65 \%) . \mathrm{mp} 248-250{ }^{\circ} \mathrm{C} ; R_{\mathrm{f}} 0.56$ (ethyl acetate); ${ }^{1} \mathrm{H}$ NMR $(400 \mathrm{MHz}$; acetone- $\left.d_{6}\right) \delta$ ppm: $6.75\left(2 \mathrm{H}\right.$, br s, $\left.\mathrm{SO}_{2} \mathrm{NH}_{2}\right), 7.07\left(1 \mathrm{H},{ }^{4} J=2.9 \mathrm{~Hz}\right.$, 
$\left.\mathrm{H}_{\text {phenyl }}\right), 7.18\left(1 \mathrm{H}, \mathrm{dd},{ }^{3} J=8.9 \mathrm{~Hz},{ }^{4} J=2.9 \mathrm{~Hz}, \mathrm{H}_{\text {phenyl }}\right), 7.30(2 \mathrm{H}$, $\left.\mathrm{t},{ }^{3} J=8.8 \mathrm{~Hz}, \mathrm{H}_{\text {F-phenyl-3/5 }}\right), 7.87\left(2 \mathrm{H}, \mathrm{dd},{ }^{3} J=8.9 \mathrm{~Hz},{ }^{4} J=5.5 \mathrm{~Hz}\right.$, $\left.\mathrm{H}_{\mathrm{F}-\text { phenyl-2/6 }}\right)$, 7.99-8.05 (4H, m), $8.25\left(1 \mathrm{H}, \mathrm{d},{ }^{3} \mathrm{~J}=8.9 \mathrm{~Hz}, \mathrm{H}_{\text {phenyl }}\right)$, $8.68(1 \mathrm{H}, \mathrm{s}, \mathrm{OH}), 10.86(1 \mathrm{H}, \mathrm{br} \mathrm{s}, \mathrm{NH}) ;{ }^{13} \mathrm{C}$ NMR $(101 \mathrm{MHz}$; acetone- $\left.d_{6}\right) \delta$ ppm: $116.1\left(\mathrm{~d},{ }^{2} J=22 \mathrm{~Hz}\right), 119.2,121.1,125.3^{*}$, $127.3^{*}, 128.6,129.1,132.0 *, 133.5$ (d, $\left.{ }^{3} J=9 \mathrm{~Hz}\right), 135.6\left(\mathrm{~d},{ }^{4} J=3\right.$ $\mathrm{Hz}), 138.9^{*}, 147.8^{*}, 154.2,164.6,166.1$ (d, $\left.{ }^{1} J=252 \mathrm{~Hz}\right), 197.3$, * deuterium isotope shifts were observed in the range of 11 to 101 ppb; ${ }^{19} \mathrm{~F}$ NMR $\left(376 \mathrm{MHz}\right.$; acetone- $\left.d_{6}\right) \delta$ ppm: -108.5; ESI-MS $\left(\mathrm{ES}^{+}\right) \mathrm{m} / z 437[\mathrm{M}+\mathrm{Na}]^{+}(100 \%), 478\left[\mathrm{M}+\mathrm{Na}+\mathrm{CH}_{3} \mathrm{CN}\right]^{+}$, (72).

$\mathrm{N}$-[2-(4-Methoxybenzoyl)phenyl]-4-(methylsulfonyl)benzamide (2f). Purification of the raw product obtained by general procedure A was carried out by washing the raw precipitate in methanol, filtration and drying under vacuum. Starting from 1d (454 mg, $2.0 \mathrm{mmol}$ ) and 4-(methylsulfonyl)benzoyl chloride (484 $\mathrm{mg}, 2.2 \mathrm{mmol}$ ), $2 \mathrm{f}$ was obtained as pale yellow solid $(689 \mathrm{mg}$, 84\%). mp 170-171 ${ }^{\circ} \mathrm{C}$ (lit., ${ }^{11} 160-161{ }^{\circ} \mathrm{C}$ ); $R_{\mathrm{f}} 0.25$ (petroleum ether-ethyl acetate $50: 50) ;{ }^{1} \mathrm{H}$ NMR (400 MHz; DMSO- $\left.d_{6}\right) \delta$ ppm: $3.26\left(3 \mathrm{H}, \mathrm{s}, \mathrm{SO}_{2} \mathrm{CH}_{3}\right), 3.81\left(3 \mathrm{H}, \mathrm{s}, \mathrm{OCH}_{3}\right), 7.01\left(2 \mathrm{H}, \mathrm{d},{ }^{3} J=\right.$ $\left.8.8 \mathrm{~Hz}, \mathrm{H}_{\text {anisole }}\right), 7.36\left(1 \mathrm{H}, \mathrm{t},{ }^{3} J=7.4 \mathrm{~Hz}, \mathrm{H}_{\text {arom }}\right), 7.48\left(1 \mathrm{H}, \mathrm{d},{ }^{3} J=\right.$ $\left.7.6 \mathrm{~Hz},{ }^{4} J=1.2 \mathrm{~Hz}, \mathrm{H}_{\text {arom }}\right), 7.64\left(1 \mathrm{H}, \mathrm{t},{ }^{3} J=8.0 \mathrm{~Hz},{ }^{4} J=1.3 \mathrm{~Hz}\right.$, $\left.\mathrm{H}_{\text {arom }}\right), 7.69\left(2 \mathrm{H}, \mathrm{d},{ }^{3} J=8.8 \mathrm{~Hz}, \mathrm{H}_{\text {anisole }}\right), 7.73\left(1 \mathrm{H}, \mathrm{d},{ }^{3} J=7.9 \mathrm{~Hz}\right.$, $\left.\mathrm{H}_{\text {arom }}\right), 7.90\left(2 \mathrm{H}, \mathrm{d},{ }^{3} J=8.4 \mathrm{~Hz}, \mathrm{H}_{\text {arom }}\right), 8.01\left(2 \mathrm{H}, \mathrm{d},{ }^{3} J=8.4 \mathrm{~Hz}\right.$, $\left.\mathrm{H}_{\text {arom }}\right), 10.77(1 \mathrm{H}, \mathrm{s}, \mathrm{NH})$; ESI-MS $\left(\mathrm{ES}^{+}\right) \mathrm{m} / z: 432[\mathrm{M}+\mathrm{Na}]^{+}$ $(100 \%)$.

4-(Aminosulfonyl)- $\mathrm{N}$-[2-(4-methoxybenzoyl)phenyl]benzamide (2g). Purification of the raw product obtained by general procedure A was carried out by column chromatography (petroleum ether-ethyl acetate 30 : 70). Starting from 1d (600 $\mathrm{mg}, 2.64 \mathrm{mmol}$ ) and 4-sulfamoylbenzoyl chloride (640 mg, 2.92 $\mathrm{mmol}$ ), $2 \mathrm{~g}$ was obtained as pale yellow solid (853 $\mathrm{mg}, 78 \%$ ). $\mathrm{mp}$ 162-166 ${ }^{\circ} \mathrm{C}$ (lit., ${ }^{11} 173-174{ }^{\circ} \mathrm{C}$ ); ${ }^{1} \mathrm{H}$ NMR (400 MHz; DMSO- $\left.d_{6}\right) \delta$ ppm: $3.81\left(3 \mathrm{H}, \mathrm{s}, \mathrm{OCH}_{3}\right), 7.01\left(2 \mathrm{H}, \mathrm{d},{ }^{3} \mathrm{~J}=8.8 \mathrm{~Hz}, \mathrm{H}_{\text {anisole }}\right), 7.35$ $\left(1 \mathrm{H}, \mathrm{t},{ }^{3} J=7.6 \mathrm{~Hz},{ }^{4} J=1.0 \mathrm{~Hz}, \mathrm{H}_{\text {arom }}\right), 7.48\left(1 \mathrm{H}, \mathrm{d},{ }^{3} J=7.7 \mathrm{~Hz}\right.$, $\left.{ }^{4} J=1.5 \mathrm{~Hz}, \mathrm{H}_{\text {arom }}\right), 7.51\left(2 \mathrm{H}, \mathrm{s}, \mathrm{NH}_{2}\right), 7.64\left(1 \mathrm{H}, \mathrm{t},{ }^{3} J=7.8 \mathrm{~Hz},{ }^{4} J=\right.$ $\left.1.5 \mathrm{~Hz}, \mathrm{H}_{\text {arom }}\right), 7.69\left(2 \mathrm{H}, \mathrm{d},{ }^{3} J=8.8 \mathrm{~Hz}, \mathrm{H}_{\text {anisole }}\right), 7.74\left(1 \mathrm{H}, \mathrm{d},{ }^{3} J=\right.$ $\left.7.6 \mathrm{~Hz}, \mathrm{H}_{\text {arom }}\right), 7.82\left(2 \mathrm{H}, \mathrm{d},{ }^{3} J=8.5 \mathrm{~Hz}, \mathrm{H}_{\text {arom }}\right), 7.88\left(2 \mathrm{H}, \mathrm{d},{ }^{3} J=\right.$ $\left.8.4 \mathrm{~Hz}, \mathrm{H}_{\text {arom }}\right), 10.71(1 \mathrm{H}, \mathrm{s}, \mathrm{NH}) ;{ }^{13} \mathrm{C}$ NMR (101 MHz; DMSO- $\left.d_{6}\right)$ $\delta$ ppm: $55.6\left(\mathrm{OCH}_{3}\right), 113.6,124.6,124.9,125.7,128.0,129.8$, 130.2, 131.7, 131.7, 132.0, 136.2, 137.2, 146.6, 162.9, 164.3 (CO), 194.1 (CO); ESI-MS $\left(\mathrm{ES}^{+}\right) \mathrm{m} / z: 433[\mathrm{M}+\mathrm{Na}]^{+}(100 \%)$.

General procedure B for the synthesis of 2-(4-sulfonylphenyl)3-phenyl-1H-indoles (3a-3g)

Under nitrogen atmosphere, $\operatorname{TiCl}_{4}(146.2 \mu \mathrm{L}, 253 \mathrm{mg}, 1.3 \mathrm{mmol})$ was added to a suspension of the appropriate benzamide (0.62 $\mathrm{mmol}$ ) and $\mathrm{Zn}$ (170 $\mathrm{mg}, 2.5 \mathrm{mmol})$ in THF (5.5 mL). The resulting mixture was heated to $65^{\circ} \mathrm{C}$ for $1.5 \mathrm{~h}$. The solvent was removed and the mixture was purified as described below.

3-(Fluorophenyl)-2-[4-(methylsulfonyl)phenyl]-1H-indole (3a). Synthesis and characterization of compound $\mathbf{3 a}$ was recently reported. ${ }^{30}$ Compound 3a was used for the discussed experiments. UV/vis: $\lambda_{\text {max }} / \mathrm{nm}$ 236, 249, $336\left(\varepsilon / \mathrm{dm}^{3} \mathrm{~mol}^{-1} \mathrm{~cm}^{-1}\right.$ 22 400, 20 300, 16 100); fluorescence: $\lambda_{\text {exc }}=343, \lambda_{\text {em }}=454 \mathrm{~nm}$. Crystals suitable for X-ray crystallography were obtained by slow evaporation from ethyl acetate at room temperature. Detailed results of the single-crystal X-ray structure determination are given below and in the ESI. +

2-[4-(Aminosulfonyl)phenyl]-3-(4-fluorophenyl)-1H-indole (3b). Purification of the crude product obtained by general procedure B was carried out by column chromatography (petroleum etherethyl acetate $50: 50)$. Starting from $2 \mathbf{b}(220 \mathrm{mg}, 0.54 \mathrm{mmol}), 3 \mathbf{b}$ was obtained as colorless solid (168 mg, 85\%). mp 238-239 ${ }^{\circ} \mathrm{C}$ (lit., ${ }^{11} 228-230{ }^{\circ} \mathrm{C}$ ); $R_{\mathrm{f}} 0.26$ (petroleum ether-ethyl acetate 50 : 50); UV/vis: $\lambda_{\text {max }} / \mathrm{nm} \mathrm{253,} 328\left(\varepsilon / \mathrm{dm}^{3} \mathrm{~mol}^{-1} \mathrm{~cm}^{-1} 20800\right.$, 17 000); fluorescence: $\lambda_{\text {exc }}=338, \lambda_{\mathrm{em}}=450 \mathrm{~nm} ;{ }^{1} \mathrm{H}$ NMR (400 $\mathrm{MHz}$; $\left.\mathrm{CD}_{3} \mathrm{CN}\right) \delta$ ppm: $5.68\left(2 \mathrm{H}\right.$, br s, $\left.\mathrm{SO}_{2} \mathrm{NH}_{2}\right), 7.13\left(1 \mathrm{H}, \mathrm{t},{ }^{3} J=\right.$ $\left.8.0 \mathrm{~Hz},{ }^{3} J=7.1 \mathrm{~Hz}, \mathrm{H}_{\text {indol }}\right), 7.18\left(2 \mathrm{H}, \mathrm{t},{ }^{3} J=9.0 \mathrm{~Hz}, \mathrm{H}_{\mathrm{F}-\text { phenyl-3/5}}\right)$, $7.26\left(1 \mathrm{H}, \mathrm{t},{ }^{3} J=8.3 \mathrm{~Hz},{ }^{3} J=7.1 \mathrm{~Hz},{ }^{4} J 1.1 \mathrm{~Hz}, \mathrm{H}_{\text {indol }}\right), 7.39(2 \mathrm{H}$, $\left.\mathrm{dd},{ }^{3} J=8.9 \mathrm{~Hz},{ }^{4} J=5.5 \mathrm{~Hz}, \mathrm{H}_{\mathrm{F}-\text { phenyl-2/6 }}\right), 7.49-7.54(2 \mathrm{H}, \mathrm{m}$, $\left.\mathrm{H}_{\text {indol }}\right), 7.59\left(2 \mathrm{H}, \mathrm{d},{ }^{3} J=8.7 \mathrm{~Hz}, \mathrm{H}_{\text {phenyl }}\right), 7.81\left(2 \mathrm{H}, \mathrm{d},{ }^{3} J=8.7 \mathrm{~Hz}\right.$, $\mathrm{H}_{\text {phenyl }}$ ), 9.78 (1H, br s, NH); ${ }^{13} \mathrm{C} \mathrm{NMR}\left(101 \mathrm{MHz} ; \mathrm{CD}_{3} \mathrm{CN}\right) \delta \mathrm{ppm}$ : 113.1, 116.4, 117.1 (d, ${ }^{2} J=22 \mathrm{~Hz}$ ), 120.7, 122.1, 124.8, 127.9, 130.0, 130.1, 132.7 (d, $\left.{ }^{4} \mathrm{~J}=3 \mathrm{~Hz}\right), 133.5$ (d, $\left.{ }^{3} \mathrm{~J}=8 \mathrm{~Hz}\right), 134.1$, 138.0, 138.1, 143.5, 163.4 (d, $\left.{ }^{1} J=243 \mathrm{~Hz}\right) ;{ }^{19} \mathrm{~F}$ NMR $(376 \mathrm{MHz}$; $\left.\mathrm{CD}_{3} \mathrm{CN}\right) \delta$ ppm: -118.0; ESI-MS (ES $\left.{ }^{-}\right) \mathrm{m} / z 365[\mathrm{M}-\mathrm{H}]^{-}(100 \%)$.

3-(4-Fluorophenyl)-5-methyl-2-[4-(methylsulfonyl)phenyl]-1Hindole (3c). Purification of the crude product obtained by general procedure B was carried out by column chromatography (chloroform-methanol 90 : 10). Starting from 2c (400 mg, 0.97 $\mathrm{mmol}$ ), 3c was obtained as beige solid (221 mg, 60\%). mp 239$242{ }^{\circ} \mathrm{C} ; R_{\mathrm{f}} 0.72$ (chloroform-methanol 90 : 10); UV/vis: $\lambda_{\max } / \mathrm{nm}$ 239, $339\left(\varepsilon / \mathrm{dm}^{3} \mathrm{~mol}^{-1} \mathrm{~cm}^{-1} 56200,20300\right)$; fluorescence: $\lambda_{\mathrm{exc}}=$ $345, \lambda_{\mathrm{em}}=476 \mathrm{~nm} ;{ }^{1} \mathrm{H}$ NMR (400 MHz; acetone- $\left.d_{6}\right) \delta$ ppm: 2.40 $\left(3 \mathrm{H}, \mathrm{s}, \mathrm{CH}_{3}\right), 3.13\left(3 \mathrm{H}, \mathrm{s}, \mathrm{SO}_{2} \mathrm{CH}_{3}\right), 7.08\left(1 \mathrm{H}, \mathrm{dd},{ }^{3} J=8.4 \mathrm{~Hz},{ }^{4} J=\right.$ $\left.1.4 \mathrm{~Hz}, \mathrm{H}_{\text {indol }}\right), 7.21\left(2 \mathrm{H}, \mathrm{t},{ }^{3} J=8.9 \mathrm{~Hz}, \mathrm{H}_{\mathrm{F}-\text { phenyl-3/5 }}\right), 7.32(1 \mathrm{H}, \mathrm{d}$, $\left.{ }^{4} J=0.6 \mathrm{~Hz}, \mathrm{H}_{\text {indol }}\right), 7.38-7.45\left(3 \mathrm{H}, \mathrm{m},{ }^{3} \mathrm{~J}=8.4 \mathrm{~Hz},{ }^{3} \mathrm{~J}=8.8 \mathrm{~Hz}\right.$, $\left.{ }^{4} J=5.5 \mathrm{~Hz}, 2 \mathrm{H}_{\text {F-phenyl }} / 1 \mathrm{H}_{\text {indol }}\right), 7.71\left(2 \mathrm{H}, \mathrm{d},{ }^{3} J=8.6 \mathrm{~Hz}, \mathrm{H}_{\text {phenyl }}\right)$, $7.89\left(2 \mathrm{H}, \mathrm{d},{ }^{3} J=8.6 \mathrm{~Hz}, \mathrm{H}_{\text {phenyl }}\right), 10.72(1 \mathrm{H}, \mathrm{br} \mathrm{s}, \mathrm{NH}) ;{ }^{13} \mathrm{C} \mathrm{NMR}$ (101 MHz; acetone- $d_{6}$ ) $\delta$ ppm: 21.6, 44.2, 112.2*, 115.8*, 116.5 $\left(\mathrm{d},{ }^{2} J=21 \mathrm{~Hz}\right), 119.6,125.8,128.4,129.3 *, 129.8,130.3,132.3$ (d, $\left.{ }^{4} J=3 \mathrm{~Hz}\right), 132.8$ (d, $\left.{ }^{3} J=8 \mathrm{~Hz}\right), 133.2 *, 136.2 *, 138.8 *, 140.6$, $162.6\left(\mathrm{~d},{ }^{1} \mathrm{~J}=246 \mathrm{~Hz}\right)$, * deuterium isotope shifts were observed in the range of 36 to $143 \mathrm{ppb} ;{ }^{19} \mathrm{~F}$ NMR (376 MHz; acetone- $\left.d_{6}\right) \delta$ ppm: -117.9; ESI-MS (ES $\left.{ }^{-}\right) \mathrm{m} / z 378[\mathrm{M}-\mathrm{H}]^{-}(100 \%)$.

2-[4-(Aminosulfonyl)phenyl]-3-(4-fluorophenyl)-5-methyl-1Hindole (3d). Purification of the crude product obtained by general procedure B was carried out by column chromatography ((1) chloroform-methanol $90: 10$; (2) petroleum ether-ethyl acetate $50: 50)$ and preparative HPLC (RP-18, $\mathrm{CH}_{3} \mathrm{CN}-\mathrm{H}_{2} \mathrm{O}$ (with $0.1 \%$ TFA) $50: 50 \rightarrow 70: 30)$. Starting from $2 d(220 \mathrm{mg}$, $0.54 \mathrm{mmol}$ ), 3d was obtained as colorless solid (44 mg, 21\%). $\mathrm{mp} 242-244{ }^{\circ} \mathrm{C} ; R_{\mathrm{f}} 0.38$ (petroleum ether-ethyl acetate $50: 50$ ); UV/vis: $\lambda_{\max } / \mathrm{nm} 238,333\left(\varepsilon / \mathrm{dm}^{3} \mathrm{~mol}^{-1} \mathrm{~cm}^{-1} 40600,21000\right)$; fluorescence: $\lambda_{\mathrm{exc}}=339, \lambda_{\mathrm{em}}=451 \mathrm{~nm} ;{ }^{1} \mathrm{H}$ NMR $(400 \mathrm{MHz}$; acetone- $\left.d_{6}\right) \delta$ ppm: $2.39\left(3 \mathrm{H}, \mathrm{s}, \mathrm{CH}_{3}\right), 6.60\left(2 \mathrm{H}\right.$, br s, $\left.\mathrm{SO}_{2} \mathrm{NH}_{2}\right)$, $7.07\left(1 \mathrm{H}, \mathrm{dd},{ }^{3} J=8.3 \mathrm{~Hz},{ }^{4} J=1.4 \mathrm{~Hz}, \mathrm{H}_{\text {indol }}\right), 7.21\left(2 \mathrm{H}, \mathrm{t},{ }^{3} J=8.9\right.$ $\left.\mathrm{Hz}, \mathrm{H}_{\text {F-phenyl-3/5 }}\right), 7.33\left(1 \mathrm{H}, \mathrm{d},{ }^{4} J=0.6 \mathrm{~Hz}, \mathrm{H}_{\text {indol }}\right), 7.37-7.45(3 \mathrm{H}$, $\left.\mathrm{m},{ }^{3} J=8.9 \mathrm{~Hz},{ }^{3} J=8.3 \mathrm{~Hz},{ }^{4} J=5.5 \mathrm{~Hz}, 2 \mathrm{H}_{\mathrm{F}-\text { phenyl }} / 1 \mathrm{H}_{\text {indol }}\right), 7.63$ $\left(2 \mathrm{H}, \mathrm{d},{ }^{3} J=8.6 \mathrm{~Hz}, \mathrm{H}_{\text {phenyl }}\right), 7.84\left(2 \mathrm{H}, \mathrm{d},{ }^{3} J=8.6 \mathrm{~Hz}, \mathrm{H}_{\text {phenyl }}\right)$, 10.66 (1H, br s, NH); ${ }^{13} \mathrm{C}$ NMR (101 MHz; acetone- $\left.d_{6}\right) \delta$ ppm: 21.6, 112.1* $115.2^{*}, 116.4$ (d, $\left.{ }^{2} J=21 \mathrm{~Hz}\right), 119.5,125.6,127.2$, 129.1, 129.8*, 130.1, 132.5 (d, $\left.{ }^{4} J=3 \mathrm{~Hz}\right), 132.8$ (d, ${ }^{3} J=8 \mathrm{~Hz}$ ), 
133.6, 136.1* $137.2^{*}, 143.6^{*}, 162.6\left(\mathrm{~d},{ }^{1} \mathrm{~J}=244 \mathrm{~Hz}\right), *$ deuterium isotope shifts were observed in the range of 33 to $144 \mathrm{ppb} ;{ }^{19} \mathrm{~F}$ NMR (376 MHz; acetone- $\left.d_{6}\right) \delta$ ppm: -118.1; ESI-MS $\left(\mathrm{MS}^{-}\right) \mathrm{m} / z$ $379[\mathrm{M}-\mathrm{H}]^{-}(100 \%)$.

2-[4-(Aminosulfonyl)phenyl]-3-(4-fluorophenyl)-5-hydroxy-1Hindole (3e). Purification of the crude product obtained by general procedure B was carried out by column chromatography (chloroform-methanol $90: 10)$. Starting from 2e (240 mg, $0.58 \mathrm{mmol}$ ), 3e was obtained as colorless solid (119 $\mathrm{mg}, 54 \%$ ). mp 244-247 ${ }^{\circ} \mathrm{C} ; R_{\mathrm{f}} 0.19$ (petroleum ether-ethyl acetate $50: 50$ ); UV/vis: $\lambda_{\max } / \mathrm{nm} 236,341\left(\varepsilon / \mathrm{dm}^{3} \mathrm{~mol}^{-1} \mathrm{~cm}^{-1} 43300,20500\right)$; fluorescence: $\lambda_{\text {exc }}=345, \lambda_{\mathrm{em}}=481 \mathrm{~nm} ;{ }^{1} \mathrm{H}$ NMR $(400 \mathrm{MHz}$; acetone- $\left.d_{6}\right) \delta$ ppm: $6.60\left(2 \mathrm{H}\right.$, br s, $\left.\mathrm{SO}_{2} \mathrm{NH}_{2}\right), 6.83\left(1 \mathrm{H}, \mathrm{dd},{ }^{3} J=8.7\right.$ $\left.\mathrm{Hz},{ }^{4} J=2.3 \mathrm{~Hz}, \mathrm{H}_{\text {indole }-6}\right), 6.95\left(1 \mathrm{H}, \mathrm{d},{ }^{4} J=2.3 \mathrm{~Hz}, \mathrm{H}_{\text {indole }-4}\right), 7.20$ $\left(2 \mathrm{H}, \mathrm{t},{ }^{3} \mathrm{~J}=8.9 \mathrm{~Hz}, \mathrm{H}_{\mathrm{F}-\text { phenyl-3/5 }}\right), 7.34\left(1 \mathrm{H}, \mathrm{d},{ }^{3} \mathrm{~J}=8.6 \mathrm{~Hz}, \mathrm{H}_{\text {indole- }}\right)$, $7.40\left(2 \mathrm{H}, \mathrm{dd},{ }^{3} J=8.8 \mathrm{~Hz},{ }^{4} J=5.5 \mathrm{~Hz}, \mathrm{H}_{\mathrm{F}-\text { phenyl-2/6}}\right), 7.61(2 \mathrm{H}, \mathrm{d}$, $\left.{ }^{3} J=8.7 \mathrm{~Hz}, \mathrm{H}_{\text {phenyl }}\right), 7.78(1 \mathrm{H}$, br s, OH$) ; 7.83\left(2 \mathrm{H}, \mathrm{d},{ }^{3} J=8.7 \mathrm{~Hz}\right.$, $\left.\mathrm{H}_{\text {phenyl }}\right), 10.54$ (1H, br s, NH); ${ }^{13} \mathrm{C}$ NMR (101 MHz; CD $\left.3 \mathrm{CN}\right) \delta$ ppm: 103.6*, 113.0*, 114.3*, 114.9*, 116.3 (d, $\left.{ }^{2} J=21 \mathrm{~Hz}\right), 127.2$, 129.0, 130.3*, 132.4*, 132.6, 132.7 (d, ${ }^{3} J=8 \mathrm{~Hz}$ ), 134.1*, 137.3 $\left(\mathrm{d},{ }^{4} J=4 \mathrm{~Hz}\right)^{*}, 143.5^{*}, 152.8^{*}, 162.5\left(\mathrm{~d},{ }^{1} J=244 \mathrm{~Hz}\right)$, *deuterium isotope shifts were observed in the range of 12 to $140 \mathrm{ppb} ;{ }^{19} \mathrm{~F}$ NMR (376 MHz; acetone- $\left.d_{6}\right) \delta$ ppm: 118.2; ESI-MS $\left(\mathrm{MS}^{+}\right) \mathrm{m} / z 383[\mathrm{M}+\mathrm{H}]^{+}(100 \%)$.

3-(4-Methoxyphenyl)-2-[4-(methylsulfonyl)phenyl]-1H-indole (3f). Purification of the crude product obtained by general procedure B was carried out by column chromatography (petroleum ether-ethyl acetate $30: 70)$. Starting from 2 f $(360$ $\mathrm{mg}, 0.88 \mathrm{mmol}), 3 \mathrm{f}$ was obtained as a pale yellow solid (182 mg, $55 \%$ ). mp 222-226 ${ }^{\circ} \mathrm{C}$ (lit., ${ }^{11} 218.5-220.5{ }^{\circ} \mathrm{C}$ ); $R_{\mathrm{f}} 0.47$ (petroleum ether-ethyl acetate $30: 70)$; UV/vis: $\lambda_{\max } / \mathrm{nm} 237,256,332(\varepsilon /$ $\left.\mathrm{dm}^{3} \mathrm{~mol}^{-1} \mathrm{~cm}^{-1} 28700,25400,16000\right)$; fluorescence: $\lambda_{\text {exc }}=$ $354, \lambda_{\mathrm{em}}=492 \mathrm{~nm} ;{ }^{1} \mathrm{H}$ NMR (400 MHz; DMSO- $\left.d_{6}\right) \delta$ ppm: 3.25 $\left(3 \mathrm{H}, \mathrm{s}, \mathrm{SO}_{2} \mathrm{CH}_{3}\right), 3.80\left(3 \mathrm{H}, \mathrm{s}, \mathrm{OCH}_{3}\right), 7.02\left(2 \mathrm{H}, \mathrm{d},{ }^{3} J=8.8 \mathrm{~Hz}\right.$, $\left.\mathrm{H}_{\text {anisole }}\right), 7.06\left(1 \mathrm{H}, \mathrm{t},{ }^{3} J=8.0 \mathrm{~Hz},{ }^{3} J=7.0 \mathrm{~Hz},{ }^{4} J=0.9 \mathrm{~Hz}, \mathrm{H}_{\text {arom }}\right)$, $7.21\left(1 \mathrm{H}, \mathrm{t},{ }^{3} J=8.1 \mathrm{~Hz},{ }^{3} J=7.1 \mathrm{~Hz},{ }^{4} J=1.1 \mathrm{~Hz}, \mathrm{H}_{\text {arom }}\right), 7.28(2 \mathrm{H}$, $\left.\mathrm{d},{ }^{3} J=8.7 \mathrm{~Hz}, \mathrm{H}_{\text {anisole }}\right), 7.45\left(1 \mathrm{H}, \mathrm{d},{ }^{3} J=8.0 \mathrm{~Hz}, \mathrm{H}_{\text {arom }}\right), 7.48(1 \mathrm{H}$, $\left.\mathrm{d},{ }^{3} J=8.1 \mathrm{~Hz}, \mathrm{H}_{\text {arom }}\right), 7.69\left(2 \mathrm{H}, \mathrm{d},{ }^{3} J=8.7 \mathrm{~Hz}, \mathrm{H}_{\text {arom }}\right), 7.90(2 \mathrm{H}$, $\left.\mathrm{d},{ }^{3} J=8.6 \mathrm{~Hz}, \mathrm{H}_{\text {arom }}\right), 11.70(1 \mathrm{H}, \mathrm{s}, \mathrm{NH}) ;{ }^{13} \mathrm{C} \mathrm{NMR}(101 \mathrm{MHz}$; DMSO- $\left.d_{6}\right) \delta$ ppm: 43.4, 55.0, 111.7, 114.4, 115.3, 119.1, 119.9, $122.8,126.6,127.1,128.2 *$, 130.9, 131.5, 136.4, 137.5, 139.0, 158.0, *two carbon species with equivalent chemical shift; ESIMS $\left(\mathrm{ES}^{+}\right) \mathrm{m} / z 400[\mathrm{M}+\mathrm{Na}]^{+}(100 \%)$.

2-[4-(Aminosulfonyl)phenyl]-3-(4-methoxyphenyl)-1H-indole (3g). Purification of the crude product obtained by general procedure B was carried out by column chromatography (petroleum ether-ethyl acetate $20: 80)$. Starting from $2 \mathbf{g}(300$ $\mathrm{mg}, 0.73 \mathrm{mmol}$ ), $3 \mathrm{~g}$ was obtained as pale yellow solid (184 mg, 48\%). mp 282-285 ${ }^{\circ} \mathrm{C}$ (lit., ${ }^{11} 280-282{ }^{\circ} \mathrm{C}$ ), $R_{\mathrm{f}} 0.51$ (petroleum ether-ethyl acetate $20: 80)$; UV/vis: $\lambda_{\max } / \mathrm{nm} 237,325\left(\varepsilon / \mathrm{dm}^{3}\right.$ $\mathrm{mol}^{-1} \mathrm{~cm}^{-1} 37$ 100, 16 100); fluorescence: $\lambda_{\text {exc }}=345, \lambda_{\text {em }}=482$ $\mathrm{nm} ;{ }^{1} \mathrm{H}$ NMR (400 MHz; DMSO- $\left.d_{6}\right) \delta \mathrm{ppm}: 3.80\left(3 \mathrm{H}, \mathrm{s}, \mathrm{OCH}_{3}\right)$, 6.79-7.08 (3H, m, $\left.{ }^{3} J=7.7 \mathrm{~Hz}, \mathrm{H}_{\text {anisole }} / \mathrm{H}_{\text {arom. }}\right), 7.19\left(1 \mathrm{H}, \mathrm{t},{ }^{3} J=\right.$ $\left.7.9 \mathrm{~Hz}, \mathrm{H}_{\text {arom }}\right), 7.27\left(2 \mathrm{H}, \mathrm{d},{ }^{3} J=7.9 \mathrm{~Hz}, \mathrm{H}_{\text {anisole }}\right), 7.39(2 \mathrm{H}, \mathrm{s}$, $\mathrm{NH}_{2}$ ), 7.43-7.49 (2H, m, $\left.\mathrm{H}_{\text {arom }}\right), 7.61\left(2 \mathrm{H}, \mathrm{d},{ }^{3} J=8.2 \mathrm{~Hz}, \mathrm{H}_{\text {arom }}\right)$, $7.79\left(2 \mathrm{H}, \mathrm{d},{ }^{3} J\right.$ 8.0, $\left.\mathrm{H}_{\text {arom }}\right), 11.64(1 \mathrm{H}, \mathrm{s}, \mathrm{NH}) ;{ }^{13} \mathrm{C} \mathrm{NMR}(101 \mathrm{MHz}$; DMSO- $\left.d_{6}\right) \delta$ ppm: 55.1, 111.6, 114.4, 114.6, 119.0, 119.9, 122.6,
125.9, 126.8, 128.1*, 130.9, 132.0, 135.9, 136.3, 142.4, 158.0, *two carbon species with equivalent chemical shift; ESI-MS $\left(\mathrm{ES}^{+}\right) \mathrm{m} / z 401[\mathrm{M}+\mathrm{Na}]^{+}(80 \%)$.

$\boldsymbol{N}$-(\{4-[3-(4-Methoxyphenyl)-1H-indol-2-yl]phenyl $\}$ sulfonyl)acetamide (3h). The sulfonamide $3 \mathrm{~g}(240 \mathrm{mg}, 0.6 \mathrm{mmol})$ was suspended in acetic acid $(5 \mathrm{~mL})$. Acetyl chloride $(200 \mu \mathrm{L}$, $2.8 \mathrm{mmol}$ ) was added and the mixture was stirred under reflux for $90 \mathrm{~min}$. After cooling, the acetic acid was removed under reduced pressure and the residue was purified by column chromatography (petroleum ether-ethyl acetate $20: 80$ ). 3h was obtained as pale green powder $(176 \mathrm{mg}, 70 \%) . \mathrm{mp} 96-100{ }^{\circ} \mathrm{C} ; R_{\mathrm{f}}$ 0.32 (petroleum ether-ethyl acetate $20: 80$ ); UV/vis: $\lambda_{\max } / \mathrm{nm}$ 256, $323\left(\varepsilon / \mathrm{dm}^{3} \mathrm{~mol}^{-1} \mathrm{~cm}^{-1} 29800,18000\right)$; fluorescence: $\lambda_{\operatorname{exc}}=$ $339, \lambda_{\mathrm{em}}=452 \mathrm{~nm} ;{ }^{1} \mathrm{H}$ NMR (400 MHz; DMSO- $\left.d_{6}\right) \delta$ ppm: 1.94 $\left(3 \mathrm{H}, \mathrm{s}, \mathrm{COCH}_{3}\right), 3.80\left(3 \mathrm{H}, \mathrm{s}, \mathrm{OCH}_{3}\right), 7.02\left(2 \mathrm{H}, \mathrm{d},{ }^{3} \mathrm{~J}=8.8 \mathrm{~Hz}\right.$, $\left.\mathrm{H}_{\text {anisole }}\right), 7.06\left(1 \mathrm{H}, \mathrm{t},{ }^{3} \mathrm{~J}=8.0 \mathrm{~Hz},{ }^{3} \mathrm{~J}=7.1 \mathrm{~Hz},{ }^{4} \mathrm{~J}=0.8 \mathrm{~Hz}, \mathrm{H}_{\text {arom }}\right)$, $7.20\left(1 \mathrm{H}, \mathrm{t},{ }^{3} J=8.2 \mathrm{~Hz},{ }^{3} J=7.1 \mathrm{~Hz},{ }^{4} J=1.1 \mathrm{~Hz}, \mathrm{H}_{\text {arom }}\right), 7.27(2 \mathrm{H}$, $\left.\mathrm{d},{ }^{3} J=8.7 \mathrm{~Hz}, \mathrm{H}_{\text {anisole }}\right), 7.42-7.48\left(2 \mathrm{H}, \mathrm{m},{ }^{3} J=8.2 \mathrm{~Hz}, \mathrm{H}_{\text {arom }}\right)$, $7.66\left(2 \mathrm{H}, \mathrm{d},{ }^{3} J=8.6 \mathrm{~Hz}, \mathrm{H}_{\text {arom }}\right), 7.86\left(2 \mathrm{H}, \mathrm{d},{ }^{3} J=8.6 \mathrm{~Hz}, \mathrm{H}_{\text {arom }}\right)$, 11.68 (1H, s, NH), $12.13(1 \mathrm{H}, \mathrm{s}, \mathrm{NH}) ;{ }^{13} \mathrm{C}$ NMR (101 MHz; DMSO$\left.d_{6}\right) \delta$ ppm: 23.3, 55.1, 111.7, 114.5, 115.3, 119.2, 120.0, 122.9, 126.6, 127.8, 128.1, 128.2, 130.9, 131.6, 136.5, 137.4, 137.6, 158.1, 168.9; ESI-MS $\left(\mathrm{ES}^{+}\right) \mathrm{m} / z 443[\mathrm{M}+\mathrm{Na}]^{+}(100 \%)$.

1-(4-Fluorophenyl)-2-phenylethanone (4). 4 was synthesized as described by Singh et al. ${ }^{37}$ Starting from phenylacetyl chloride (3.3 $\mathrm{mL}, 25 \mathrm{mmol}), 4$ was obtained following this protocol and additional purification by column chromatography (petroleum ether-ethyl acetate $85: 15)$ as a colorless solid $(2.47 \mathrm{~g}, 51 \%)$. mp 80-82 ${ }^{\circ} \mathrm{C}$ (lit., ${ }^{38} 83{ }^{\circ} \mathrm{C}$ ); $R_{\mathrm{f}} 0.36$ (petroleum ether-ethyl acetate 85 : 15); ${ }^{1} \mathrm{H}$ NMR (400 MHz; $\left.\mathrm{CD}_{3} \mathrm{CN}\right) \delta \mathrm{ppm}: 4.32\left(2 \mathrm{H}, \mathrm{s}, \mathrm{CH}_{2}\right)$, $7.18-7.36$ (7H, m, $\left.\mathrm{H}_{\text {phenyl }}\right), 8.08\left(2 \mathrm{H}, \mathrm{dd},{ }^{3} J=9.0 \mathrm{~Hz},{ }^{4} J=5.5 \mathrm{~Hz}\right.$, $\mathrm{H}_{\text {F-phenyl-2/6); }}{ }^{13} \mathrm{C}$ NMR (101 MHz; $\left.\mathrm{CD}_{3} \mathrm{CN}\right) \delta \mathrm{ppm:} \mathrm{45.9,} 116.6$ (d, ${ }^{2} J=22 \mathrm{~Hz}$ ), 127.7, 129.4, 130.7, $132.2\left(\mathrm{~d},{ }^{3} J=10 \mathrm{~Hz}\right), 134.4$ (d, $\left.{ }^{4} J=3 \mathrm{~Hz}\right), 136.1,166.6\left(\mathrm{~d},{ }^{1} J=252 \mathrm{~Hz}\right), 197.3 ;{ }^{19} \mathrm{~F}$ NMR $(376$ $\left.\mathrm{MHz} ; \mathrm{CD}_{3} \mathrm{CN}\right) \delta$ ppm: -108.0 ; ESI-MS $\left(\mathrm{ES}^{+}\right) \mathrm{m} / z 215[\mathrm{M}+\mathrm{H}]^{+}$ $(100 \%)$.

\section{General procedure $\mathrm{C}$ for the synthesis of 2-[4-(methylsulfonyl) phenyl]-1-phenyl-ethanones $5 \mathrm{a}$ and $5 \mathrm{~b}$}

The reaction was carried out under Schlenk-conditions. A suspension of 4-(methylsulfonyl)phenylacetic acid (1.714 g, $8 \mathrm{mmol})$ in dichloromethane $(1.6 \mathrm{~mL})$ and 4 drops of DMF was heated to $30{ }^{\circ} \mathrm{C}$. Freshly distilled thionyl chloride $(1.00 \mathrm{~g}$, $0.60 \mathrm{~mL}, 8.48 \mathrm{mmol}$ ) was added and the mixture was stirred for $1.5 \mathrm{~h}$ at constant temperature. The solution was cooled to $15^{\circ} \mathrm{C}$ and freshly sublimated $\mathrm{AlCl}_{3}(2.02 \mathrm{~g}, 15.15 \mathrm{mmol})$ was added in portions. After $15 \mathrm{~min}$ the appropriate benzene (9.66 mmol) was dropped to the mixture and it was stirred for $2 \mathrm{~h}$. Then ethanol $(2.8 \mathrm{~mL})$ was added dropwise at $10{ }^{\circ} \mathrm{C}$, followed by dichloromethane $(20.6 \mathrm{~mL})$ and water $(10.2 \mathrm{~mL})$ over a period of $20 \mathrm{~min}$. The mixture was heated to $30{ }^{\circ} \mathrm{C}$ and the organic phase was separated, washed with $5 \mathrm{M} \mathrm{HCl}(6 \mathrm{~mL})$ and saturated $\mathrm{Na}_{2} \mathrm{CO}_{3}$ solution $(6 \mathrm{~mL})$, and concentrated by distillation to a volume of $5 \mathrm{~mL}$. Further purification was carried out as described below.

1-(4-Ethoxyphenyl)-2-[4-(methysulfonyl)phenyl]ethanone (5a). For purification of the raw product obtained by general 
procedure C, the solution was filtered to yield 5a. Furthermore, the filtrate was concentrated to dryness, washed with a small amount of petroleum ether-DCM 1:1 to obtain a further amount of 5a. Starting from 4-(methylsulfonyl)phenylacetic acid (428 mg, $2 \mathrm{mmol}$ ) and 4-ethoxybenzene (0.304 mL, $295 \mathrm{mg}, 2.41$ $\mathrm{mmol}$ ), 5a was obtained as colorless solid (192 mg, 30\%). mp $188-190{ }^{\circ} \mathrm{C}$ from ethanol (lit., ${ }^{60} 156-159{ }^{\circ} \mathrm{C}$ ); $R_{\mathrm{f}} 0.41$ (petroleum ether-ethyl acetate $50: 50) ;{ }^{1} \mathrm{H}$ NMR (400 $\left.\mathrm{MHz} \mathrm{CDCl}_{3}\right) \delta \mathrm{ppm}$ : $1.45\left(3 \mathrm{H}, \mathrm{t},{ }^{3} \mathrm{~J}=7.0 \mathrm{~Hz}, \mathrm{OCH}_{2} \mathrm{CH}_{3}\right), 3.04\left(3 \mathrm{H}, \mathrm{s}, \mathrm{SO}_{2} \mathrm{CH}_{3}\right), 4.11$ $\left(2 \mathrm{H}, \mathrm{q},{ }^{3} \mathrm{~J}=7.0 \mathrm{~Hz}, \mathrm{OCH}_{2} \mathrm{CH}_{3}\right), 4.34\left(2 \mathrm{H}, \mathrm{s}, \mathrm{CH}_{2}\right), 6.94\left(2 \mathrm{H}, \mathrm{d},{ }^{3} J=\right.$ $\left.8.9 \mathrm{~Hz}, \mathrm{H}_{\text {phenyl }}\right), 7.46\left(2 \mathrm{H}, \mathrm{d},{ }^{3} J=8.4 \mathrm{~Hz}, \mathrm{H}_{\text {phenyl }}\right), 7.90\left(2 \mathrm{H}, \mathrm{d},{ }^{3} J\right.$ $\left.=8.4 \mathrm{~Hz}, \mathrm{H}_{\text {phenyl }}\right), 7.98\left(2 \mathrm{H}, \mathrm{d},{ }^{3} J=8.9 \mathrm{~Hz}, \mathrm{H}_{\text {phenyl }}\right) ;{ }^{13} \mathrm{C}$ NMR (101 MHz; $\mathrm{CDCl}_{3}$ ) $\delta$ ppm: 14.8, 44.7, 44.9, 64.0, 114.6, 127.8, 129.2, 130.8, 131.0, 139.2, 141.5, 163.5, 194.9; ESI-MS $\left(\mathrm{MS}^{+}\right) \mathrm{m} / \mathrm{z}$ $341[\mathrm{M}+\mathrm{Na}]^{+}(100 \%), 319[\mathrm{M}+\mathrm{H}]^{+}(53), 659(24)$.

1-(4-Methoxyphenyl)-2-[4-(methysulfonyl)phenyl]ethanone (5b). For purification of the raw product obtained by general procedure $\mathrm{C}$, the solution was filtered and the resulting solid $(1.14 \mathrm{~g})$ was further purified by sublimation under reduced pressure to yield $836 \mathrm{mg}$ of compound $\mathbf{5 b}$. The residue from sublimation and the filtrate were combined, dried and further purified by column chromatography (DCM-acetone $98: 2$ ) to yield $402 \mathrm{mg}$ of compound 5b. Starting from 4-(methylsulfonyl)phenylacetic acid (1.714 g, $8 \mathrm{mmol}$ ) and 4-methoxybenzene (1.055 mL, $1.044 \mathrm{~g}, 9.66 \mathrm{mmol}$ ), 5b was obtained as colorless solid (1.24 g, 51\%). mp $172-174{ }^{\circ} \mathrm{C} ; R_{\mathrm{f}} 0.34$ (DCM-acetone $\left.98: 2\right) ;{ }^{1} \mathrm{H}$ NMR (400 MHz; $\left.\mathrm{CDCl}_{3}\right) \delta$ ppm: $3.04\left(3 \mathrm{H}, \mathrm{s}, \mathrm{SO}_{2} \mathrm{CH}_{3}\right), 3.88(3 \mathrm{H}, \mathrm{s}$, $\left.\mathrm{OCH}_{3}\right), 4.34\left(2 \mathrm{H}, \mathrm{s}, \mathrm{CH}_{2}\right), 6.96\left(2 \mathrm{H}, \mathrm{d},{ }^{3} \mathrm{~J}=8.9 \mathrm{~Hz}, \mathrm{H}_{\text {phenyl }}\right), 7.46$ $\left(2 \mathrm{H}, \mathrm{d},{ }^{3} J=8.4 \mathrm{~Hz}, \mathrm{H}_{\text {phenyl }}\right), 7.90\left(2 \mathrm{H}, \mathrm{d},{ }^{3} J=8.4 \mathrm{~Hz}, \mathrm{H}_{\text {phenyl }}\right), 7.99$ $\left(2 \mathrm{H}, \mathrm{d},{ }^{3} J=8.9 \mathrm{~Hz}, \mathrm{H}_{\text {phenyl }}\right) ;{ }^{13} \mathrm{C} \mathrm{NMR}\left(101 \mathrm{MHz} ; \mathrm{CDCl}_{3}\right) \delta \mathrm{ppm}$ : 44.7, 44.9, 55.7, 114.2, 127.8, 129.4, 130.8, 131.0, 139.2, 141.5, 164.1, 194.9; ESI-MS $\left(\mathrm{MS}^{+}\right) \mathrm{m} / z 631[2 \mathrm{M}+\mathrm{Na}]^{+}(73 \%), 368[\mathrm{M}+$ $\left.\mathrm{Na}+\mathrm{CH}_{3} \mathrm{CN}\right]^{+}$(100), $327(56), 305[\mathrm{M}+\mathrm{H}]^{+}$(72).

1-(4-Fluorophenyl)-2-[4-(methylsulfonyl)phenyl]ethanone (5c). To 4-(methylsulfonyl)phenylacetic acid (2.0 g, $9.2 \mathrm{mmol})$ was added thionyl chloride $(4.0 \mathrm{~mL}, 6.6 \mathrm{~g}, 56 \mathrm{mmol})$ and the mixture was heated to reflux until the solution became clear. The excess of thionyl chloride was removed under reduced pressure. The resulting solid was suspended in fluorobenzene $(12 \mathrm{~mL})$ and then aluminum chloride $(1.88 \mathrm{~g}, 13 \mathrm{mmol})$ was added in small portions at $20-25{ }^{\circ} \mathrm{C}$. The mixture was heated to reflux for $2 \mathrm{~h}$, cooled to room temperature and poured onto a mixture of ice and $1 \mathrm{M} \mathrm{HCl}(4 \mathrm{~mL})$. The fluorobenzene was removed by distillation under reduced pressure and the raw product was filtered off, washed with $1 \mathrm{M} \mathrm{Na}_{2} \mathrm{CO}_{3}(10 \mathrm{~mL})$ and water $(20 \mathrm{~mL})$. Recrystallization from $95 \%$ ethanol yielded $5 \mathrm{c}$ as pale beige solid $(1.13 \mathrm{~g}$, 42\%). mp 182-185 ${ }^{\circ} \mathrm{C}$ (lit., ${ }^{38} 182-183{ }^{\circ} \mathrm{C}$ ); $R_{\mathrm{f}} 0.29$ (petroleum ether-ethyl acetate $50: 50) ;{ }^{1} \mathrm{H}$ NMR (400 MHz; acetone- $\left.d_{6}\right) \delta$ ppm: $3.12\left(3 \mathrm{H}, \mathrm{s}, \mathrm{CH}_{3}\right), 4.59\left(2 \mathrm{H}, \mathrm{s}, \mathrm{CH}_{2}\right), 7.31\left(2 \mathrm{H}, \mathrm{t},{ }^{3} \mathrm{~J}=8.8 \mathrm{~Hz}\right.$, $\left.\mathrm{H}_{\text {F-phenyl-3/5}}\right), 7.59\left(2 \mathrm{H}, \mathrm{d},{ }^{3} J=8.3 \mathrm{~Hz}, \mathrm{H}_{\text {phenyl }}\right), 7.91\left(2 \mathrm{H}, \mathrm{d},{ }^{3} J=8.3\right.$ $\left.\mathrm{Hz}, \mathrm{H}_{\text {phenyl }}\right), 8.20\left(2 \mathrm{H}, \mathrm{dd},{ }^{3} J=8.9 \mathrm{~Hz},{ }^{4} J=5.5 \mathrm{~Hz}, \mathrm{H}_{\mathrm{F}-\mathrm{phenyl}-2 / 6}\right)$; ${ }^{13} \mathrm{C}$ NMR (101 MHz; acetone- $\left.d_{6}\right) \delta$ ppm: 44.4, 45.3, $116.5\left(\mathrm{~d},{ }^{2} J=\right.$ $22 \mathrm{~Hz}$ ), 128.1, 131.7, 132.2 (d, $\left.{ }^{3} J=9 \mathrm{~Hz}\right), 134.3$ (d, ${ }^{4} J=3 \mathrm{~Hz}$ ), 140.8, 142.3, 166.6 (d, $\left.{ }^{1} J=252 \mathrm{~Hz}\right), 195.7 ;{ }^{19} \mathrm{~F}$ NMR $(376 \mathrm{MHz}$; acetone- $\left.d_{6}\right) \delta$ ppm: -107.7 ; ESI-MS $\left(\mathrm{MS}^{+}\right) m / z 315[\mathrm{M}+\mathrm{Na}]^{+}$ $(100 \%)$. Single crystals were obtained as follows: 5c was crystallized from a mixture of acetone and acetonitrile saturated at the boiling heat which was slowly cooled down to room temperature overnight. This formed a small amount of tiny crystals. Then, the solution was allowed to evaporate slowly what generated crystals suitable for X-ray crystallography. Detailed results of the single-crystal X-ray structure determination are given below and in the ESI.t

2-[4-(Aminosulfonyl)phenyl]-1-(4-fluorophenyl)ethanone (5d). Chlorosulfuric acid (1.63 mL, $2.81 \mathrm{~g}, 23.9 \mathrm{mmol})$ was slowly added to compound $4(650 \mathrm{mg}, 3.03 \mathrm{mmol})$ in a flask at $-78{ }^{\circ} \mathrm{C}$ equipped with a drying tube filled with $\mathrm{CaCl}_{2}$. The mixture was allowed to warm up over a period of $60 \mathrm{~min}$ and then allowed to stir for $2 \mathrm{~h}$ at room temperature, poured over ice and extracted with ethyl acetate $(3 \times 25 \mathrm{~mL})$. The organic phase was washed with water $(10 \mathrm{~mL})$, the organic phase was separated and then $25 \%$ aq. $\mathrm{NH}_{3}(5 \mathrm{~mL})$ solution were added. The mixture was stirred for $1 \mathrm{~h}$ at room temperature. Then, the organic phase was separated, washed with $1 \mathrm{M} \mathrm{HCl}(21 \mathrm{~mL})$ and brine $(21 \mathrm{~mL})$, concentrated to $5 \mathrm{~mL}$ and stored in the fridge. The resulting solid was filtered off and petroleum ether was added to the filtrate to yield further product. The solids were combined and dried. 5d was obtained as colorless solid (303 mg, 34\%). mp 201-204 ${ }^{\circ} \mathrm{C}$ (lit., ${ }^{38} 198-204{ }^{\circ} \mathrm{C}$ ); $R_{\mathrm{f}} 0.34$ (petroleum ether-ethyl acetate $50: 50) ;{ }^{1} \mathrm{H}$ NMR (400 MHz; DMSO- $\left.d_{6}\right) \delta \mathrm{ppm}$ : $4.53\left(2 \mathrm{H}, \mathrm{s}, \mathrm{CH}_{2}\right), 7.32\left(2 \mathrm{H}, \mathrm{br} \mathrm{s}, \mathrm{SO}_{2} \mathrm{NH}_{2}\right), 7.38\left(2 \mathrm{H}, \mathrm{t},{ }^{3} J=8.9\right.$ $\left.\mathrm{Hz}, \mathrm{H}_{\mathrm{F}-\text { phenyl-3/5 }}\right), 7.44$ (2H, d, $\left.{ }^{3} J=8.3 \mathrm{~Hz}, \mathrm{H}_{\text {phenyl }}\right), 7.78(2 \mathrm{H}, \mathrm{d}$, $\left.{ }^{3} J=8.3 \mathrm{~Hz}, \mathrm{H}_{\text {phenyl }}\right), 8.14\left(2 \mathrm{H}, \mathrm{dd},{ }^{3} J=8.9 \mathrm{~Hz},{ }^{4} J=5.5 \mathrm{~Hz}, \mathrm{H}_{\mathrm{F}-}\right.$ phenyl-2/6); ${ }^{13} \mathrm{C}$ NMR (101 MHz; DMSO- $\left.d_{6}\right) \delta$ ppm: 44.3, $115.8(\mathrm{~d}$, $\left.{ }^{3} J=22 \mathrm{~Hz}\right), 125.6,130.4,131.3\left(\mathrm{~d},{ }^{3} J=10 \mathrm{~Hz}\right), 133.0\left(\mathrm{~d},{ }^{3} J=3\right.$ $\mathrm{Hz}), 139.2,142.4,165.1$ (d, $\left.{ }^{3} J=252 \mathrm{~Hz}\right), 195.7 ;{ }^{19} \mathrm{~F}$ NMR (376 MHz; DMSO- $\left.d_{6}\right) \delta$ ppm: -106.1; ESI-MS $\left(\mathrm{MS}^{+}\right) m / z 316[\mathrm{M}+\mathrm{Na}]^{+}$ (100\%).

2-Bromo-1-(4-fluorophenyl)-2-[4-(methylsulfonyl)phenyl]ethanone 5e. To a solution of $5 \mathrm{c}(1.528 \mathrm{~g}, 5.23 \mathrm{mmol})$ in $\mathrm{CHCl}_{3}$ $(22 \mathrm{~mL})$ and $\mathrm{CCl}_{4}(85 \mathrm{~mL})$ was added dropwise a solution of $\mathrm{Br}_{2}$ $(0.270 \mathrm{~mL}, 5.13 \mathrm{mmol})$ in $\mathrm{CCl}_{4}(1.5 \mathrm{~mL})$. Then, benzoyl peroxide (65 $\mathrm{mg}, 0.27 \mathrm{mmol}$ ) was added and the reaction mixture was heated to $78{ }^{\circ} \mathrm{C}$ until the brown color of the mixture originating from $\mathrm{Br}_{2}$ disappeared. The reaction mixture was cooled to room temperature, washed with $5 \% \mathrm{Na}_{2} \mathrm{CO}_{3}(20 \mathrm{~mL})$ and brine (30 mL). Purification was carried out by column chromatography (ethyl acetate-petroleum ether $5: 5$ ). In this way, 5 e was obtained as a yellow solid (1.009 g, 52\%). mp 134-141 ${ }^{\circ} \mathrm{C}$ (lit., ${ }^{47}$ 140-141 ${ }^{\circ} \mathrm{C}$ ); $R_{\mathrm{f}} 0.44$ (ethyl acetate-petroleum ether $5: 5$ ); ${ }^{1} \mathrm{H}$ NMR (400 MHz; acetone- $\left.d_{6}\right) \delta$ ppm: $3.15\left(3 \mathrm{H}, \mathrm{s}, \mathrm{SO}_{2} \mathrm{CH}_{3}\right), 7.03$ $(1 \mathrm{H}, \mathrm{s}, \mathrm{CHBr}), 7.33\left(2 \mathrm{H}, \mathrm{t},{ }^{3} \mathrm{~J}=8.8 \mathrm{~Hz}, \mathrm{H}_{\mathrm{F}-\mathrm{phenyl}-3 / 5}\right), 7.91(2 \mathrm{H}, \mathrm{d}$, $\left.{ }^{3} J=8.5 \mathrm{~Hz}, \mathrm{H}_{\text {SO2-phenyl }}\right), 7.99\left(2 \mathrm{H}, \mathrm{d},{ }^{3} J=8.6 \mathrm{~Hz}, \mathrm{H}_{\text {SO2-phenyl }}\right)$, $8.25\left(2 \mathrm{H}, \mathrm{dd},{ }^{3} J=9.0 \mathrm{~Hz},{ }^{4} J=5.4 \mathrm{~Hz}, \mathrm{H}_{\mathrm{F}-\text { phenyl-2/6 }}\right) ;{ }^{13} \mathrm{C} \mathrm{NMR}(101$ MHz; acetone- $\left.d_{6}\right) \delta$ ppm: 44.2, 48.9, $116.9\left(\mathrm{~d},{ }^{2} J=22 \mathrm{~Hz}\right), 128.5$, 131.4, 131.6 (d, $\left.{ }^{4} J=3 \mathrm{~Hz}\right), 133.1$ (d, ${ }^{3} J=10 \mathrm{~Hz}$ ), 142.7, 142.8, $166.9\left(\mathrm{~d},{ }^{1} J=254 \mathrm{~Hz}\right), 190.3 ;{ }^{19} \mathrm{~F}$ NMR $\left(376 \mathrm{MHz}\right.$; acetone- $\left.d_{6}\right) \delta$ ppm: -106.1 .

\section{General procedure D for the synthesis of 3-(4-sulfonylphenyl)- 2-phenyl-1H-indoles (3i-3l)}

A mixture of phenylhydrazine $(66 \mu \mathrm{L}, 73 \mathrm{mg}, 0.68 \mathrm{mmol})$ and the appropriate 1,2-diphenyl ethanone $(0.68 \mathrm{mmol})$ was heated to 
$130{ }^{\circ} \mathrm{C}$ for $30 \mathrm{~min}$. After cooling to room temperature, acetic acid $(4.13 \mathrm{~mL})$ and $\mathrm{BF}_{3} \cdot \mathrm{Et}_{2} \mathrm{O}(36 \mu \mathrm{L}, 40 \mathrm{mg}, 0.29 \mathrm{mmol})$ were added and the mixture was heated to reflux for $1 \mathrm{~h}$. Then, acetic acid was removed by distillation under reduced pressure. The resulting solid was suspended in water $(3 \mathrm{~mL})$, filtered, washed with a small amount of water and dried. The mixture was further purified as described below.

2-(4-Ethoxyphenyl)-3-[4-(methylsulfonyl)phenyl]- $1 \mathrm{H}$-indole (3i). Purification of the raw product obtained by general procedure D was carried out by column chromatography (petroleum etherethyl acetate $60: 40)$. Starting from $5 \mathbf{a}(216 \mathrm{mg}, 0.68 \mathrm{mmol}), 3 \mathbf{i}$ was obtained as pale yellow solid (28 mg, 10\%). $\mathrm{mp} 212-214{ }^{\circ} \mathrm{C}$; $R_{\mathrm{f}} 0.56$ (petroleum ether-ethyl acetate $50: 50$ ); UV/vis: $\lambda_{\max } / \mathrm{nm}$ 238, 300, $340\left(\varepsilon / \mathrm{dm}^{3} \mathrm{~mol}^{-1} \mathrm{~cm}^{-1} 19\right.$ 700, 17 300, 9300); fluorescence: $\lambda_{\text {exc }}=303, \lambda_{\mathrm{em}}=450 \mathrm{~nm} ;{ }^{1} \mathrm{H}$ NMR (400 MHz; acetone$\left.d_{6}\right) \delta$ ppm: $1.38\left(3 \mathrm{H}, \mathrm{t},{ }^{3} J=7.0 \mathrm{~Hz}, \mathrm{CH}_{2} \mathrm{CH}_{3}\right), 3.15(3 \mathrm{H}, \mathrm{s}$, $\left.\mathrm{SO}_{2} \mathrm{CH}_{3}\right), 4.08\left(2 \mathrm{H}, \mathrm{q},{ }^{3} J=7.0 \mathrm{~Hz}, \mathrm{CH}_{2} \mathrm{CH}_{3}\right), 6.94\left(2 \mathrm{H}, \mathrm{d},{ }^{3} J=8.8\right.$ $\left.\mathrm{Hz}, \mathrm{H}_{\text {phenyl }}\right), 7.12\left(1 \mathrm{H}, \mathrm{t},{ }^{3} \mathrm{~J}=8.0 \mathrm{~Hz},{ }^{3} \mathrm{~J}=7.1 \mathrm{~Hz},{ }^{4} \mathrm{~J}=1.0 \mathrm{~Hz}\right.$, $\left.\mathrm{H}_{\text {indol }}\right), 7.20\left(1 \mathrm{H}, \mathrm{t},{ }^{3} \mathrm{~J}=8.1 \mathrm{~Hz},{ }^{3} J=7.1 \mathrm{~Hz},{ }^{4} J=1.1 \mathrm{~Hz}, \mathrm{H}_{\text {indol }}\right)$, $7.42\left(2 \mathrm{H}, \mathrm{d},{ }^{3} J=8.9 \mathrm{~Hz}, \mathrm{H}_{\text {phenyl }}\right), 7.50\left(1 \mathrm{H}, \mathrm{d},{ }^{3} J=8.1 \mathrm{~Hz}, \mathrm{H}_{\text {indol }}\right)$, 7.63-7.69 (3H, m, $\left.{ }^{3} J=8.5 \mathrm{~Hz}, 2 \mathrm{H}_{\text {phenyl }} / 1 \mathrm{H}_{\text {indol }}\right), 7.94\left(2 \mathrm{H}, \mathrm{d},{ }^{3} J=\right.$ $\left.8.5 \mathrm{~Hz}, \mathrm{H}_{\text {phenyl }}\right), 10.71$ (1H, br s, NH); ${ }^{13} \mathrm{C}$ NMR (101 MHz; acetone- $\left.d_{6}\right) \delta$ ppm: $15.1,44.5,64.1,112.3 *, 112.3 *, 115.6,119.2$, $121.2,123.1,125.3 *, 128.4,128.9 *, 130.8,131.2,136.9 *, 137.4^{*}$, 139.2, 142.7, 160.1, *deuterium isotope shifts were observed in the range of 37 to $146 \mathrm{ppb}$; ESI-MS $\left(\mathrm{APcI}^{-}\right) \mathrm{m} / z 390[\mathrm{M}-\mathrm{H}]^{-}$ $(100 \%)$.

2-(4-Methoxyphenyl)-3-[4-(methylsulfonyl)phenyl]-1H-indole (3j). Purification of the raw product obtained by general procedure D was carried out by column chromatography (petroleum ether-ethyl acetate $60: 40)$. Starting from 5b (206 mg, 0.68 $\mathrm{mmol}$ ), $3 \mathbf{j}$ was obtained as pale yellow solid (60 $\mathrm{mg}, 23 \%$ ). $\mathrm{mp}$ 241-243 ${ }^{\circ} \mathrm{C} ; R_{\mathrm{f}} 0.40$ (petroleum ether-ethyl acetate $50: 50$ ); UV/

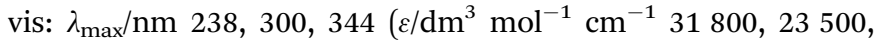
12 300); fluorescence: $\lambda_{\mathrm{exc}}=344, \lambda_{\mathrm{em}}=450 \mathrm{~nm} ;{ }^{1} \mathrm{H}$ NMR (400 MHz; acetone- $\left.d_{6}\right) \delta$ ppm: $3.15\left(3 \mathrm{H}, \mathrm{s}, \mathrm{SO}_{2} \mathrm{CH}_{3}\right), 3.83\left(3 \mathrm{H}, \mathrm{s}, \mathrm{OCH}_{3}\right)$, $6.96\left(2 \mathrm{H}, \mathrm{d},{ }^{3} \mathrm{~J}=8.7 \mathrm{~Hz}, \mathrm{H}_{\text {phenyl }}\right), 7.12\left(1 \mathrm{H}, \mathrm{t},{ }^{3} \mathrm{~J}=7.5 \mathrm{~Hz}, \mathrm{H}_{\text {indol }}\right)$, $7.20\left(1 \mathrm{H}, \mathrm{t},{ }^{3} J=7.6 \mathrm{~Hz},{ }^{4} J=0.9 \mathrm{~Hz}, \mathrm{H}_{\text {indol }}\right), 7.43\left(2 \mathrm{H}, \mathrm{d},{ }^{3} J=8.7\right.$ $\left.\mathrm{Hz}, \mathrm{H}_{\text {phenyl }}\right), 7.50\left(1 \mathrm{H}, \mathrm{d},{ }^{3} \mathrm{~J}=8.1 \mathrm{~Hz}, \mathrm{H}_{\text {indol }}\right), 7.59-7.69(3 \mathrm{H}, \mathrm{m}$, $\left.{ }^{3} J=8.3 \mathrm{~Hz}, 2 \mathrm{H}_{\text {phenyl }} / 1 \mathrm{H}_{\text {indole }}\right), 7.94\left(2 \mathrm{H}, \mathrm{d},{ }^{3} J=8.3 \mathrm{~Hz}, \mathrm{H}_{\text {phenyl }}\right)$, 10.71 (1H, br s, NH); ${ }^{13} \mathrm{C} \mathrm{NMR}$ (101 MHz; acetone- $\left.d_{6}\right) \delta$ ppm: 44.5, $55.6,112.3^{*}, 112.3^{*}, 115.1,119.2,121.2,123.1,125.5^{*}, 128.4$, 128.9*, 130.8, 131.2, 136.8*, 137.4*, 139.2, 142.6, 160.7, *deuterium isotope shifts were observed in the range of 38 to 145 $\mathrm{ppb} ; \mathrm{m} / z\left(\mathrm{ESI}^{+}\right) 378[\mathrm{M}+\mathrm{H}]^{+}(100 \%) . \mathbf{5 d}$ was also synthesized in a two-step/one-pot procedure including aminolysis and McMurry reaction and purified by column chromatography ((1) petroleum ether-ethyl acetate $50: 50 \rightarrow 0: 100$, (2) petroleum ether-ethyl acetate $50: 50)$ as previously described. ${ }^{39}$ Starting from 2-amino4'-(methylsulfonyl)benzophenone (500 mg, $1.82 \mathrm{mmol}$ ) and $p$ methoxybenzoyl chloride, 5d was obtained as colorless solid having the same spectroscopic properties as described above (218 $\mathrm{mg}, 32 \%)$. From this batch, crystals suitable for X-ray crystallography were obtained from a solution of $3 \mathbf{j}$ in ethyl acetatepetroleum ether $50: 50$ by slow evaporation at room temperature. Detailed results of the single-crystal X-ray structure determination are given below and in the ESI.t.
2-(4-Fluorophenyl)-3-[4-(methylsulfonyl)phenyl]-1H-indole (3k). Purification of the raw product obtained by general procedure D was carried out by column chromatography (petroleum ether-ethyl acetate $50: 50$ ) and preparative HPLC $\left(\mathrm{RP}-18, \mathrm{CH}_{3} \mathrm{CN}-\mathrm{H}_{2} \mathrm{O}\right.$ (with $0.1 \%$ TFA) $50: 50 \rightarrow 70: 30$ ). Starting from $5 \mathbf{c}(300 \mathrm{mg}, 1.03 \mathrm{mmol}), 3 \mathbf{k}$ was obtained as pale yellow solid (73 mg, 19\%). mp 234-235 ${ }^{\circ} \mathrm{C} ; R_{\mathrm{f}} 0.57$ (petroleum etherethyl acetate $50: 50)$; UV/vis: $\lambda_{\max } / \mathrm{nm} 238,296,337\left(\varepsilon / \mathrm{dm}^{3}\right.$ $\mathrm{mol}^{-1} \mathrm{~cm}^{-1} 44$ 700, 21 700, 12 700); fluorescence: $\lambda_{\text {exc }}=300$, $\lambda_{\mathrm{em}}=444 \mathrm{~nm} ;{ }^{1} \mathrm{H}$ NMR (400 MHz; acetone- $\left.d_{6}\right) \delta \mathrm{ppm}: 3.15(3 \mathrm{H}$, $\left.\mathrm{s}, \mathrm{SO}_{2} \mathrm{CH}_{3}\right), 7.09-7.20\left(3 \mathrm{H}, \mathrm{m},{ }^{3} J=8.9 \mathrm{~Hz},{ }^{3} \mathrm{~J}=7.5 \mathrm{~Hz},{ }^{4} \mathrm{~J}=1\right.$, $\left.2 \mathrm{H}_{\text {phenyl }} / 1 \mathrm{H}_{\text {indol }}\right), 7.23\left(1 \mathrm{H}, \mathrm{t},{ }^{3} J=7.6 \mathrm{~Hz},{ }^{4} J=1.0 \mathrm{~Hz}, \mathrm{H}_{\text {indol }}\right)$, $7.46-7.58\left(3 \mathrm{H}, \mathrm{m},{ }^{3} J=8.9 \mathrm{~Hz},{ }^{3} J=7.9 \mathrm{~Hz},{ }^{4} J=5.5 \mathrm{~Hz}, 2 \mathrm{H}_{\text {phenyl }} /\right.$ $\left.1 \mathrm{H}_{\text {indol }}\right), 7.63-7.68\left(3 \mathrm{H}, \mathrm{m},{ }^{3} J=8.4 \mathrm{~Hz},{ }^{3} J=7.8 \mathrm{~Hz}, 2 \mathrm{H}_{\text {phenyl }} /\right.$ $\left.1 \mathrm{H}_{\text {indol }}\right), 7.95\left(2 \mathrm{H}, \mathrm{d},{ }^{3} J=8.4 \mathrm{~Hz}, \mathrm{H}_{\text {phenyl }}\right), 10.83$ (1H, br s, NH); ${ }^{13} \mathrm{C}$ NMR (101 MHz; acetone- $\left.d_{6}\right) \delta$ ppm: 44.4, 112.5, 113.3, 116.5 $\left(\mathrm{d},{ }^{2} \mathrm{~J}=22 \mathrm{~Hz}\right), 119.5,121.4,123.5,128.5,128.7,129.7$ (d, ${ }^{4} J=3$ Hz), 131.7 (d, $\left.{ }^{3} J=8 \mathrm{~Hz}\right), 131.2,135.7,137.5,139.5,142.1,163.4$ $\left(\mathrm{d},{ }^{1} J=246 \mathrm{~Hz}\right) ;{ }^{19} \mathrm{~F}$ NMR $\left(376 \mathrm{MHz}\right.$; acetone- $\left.d_{6}\right) \delta \mathrm{ppm}:-115.3$; ESI-MS $\left(\mathrm{ES}^{-}\right) \mathrm{m} / \mathrm{z} 364[\mathrm{M}-\mathrm{H}]^{-}(100 \%)$.

3-[4-(Aminosulfonyl)phenyl]-2-(4-fluorophenyl)-1H-indole (31). Purification of the raw product obtained by general procedure D was carried out by column chromatography (petroleum etherethyl acetate $70: 30)$ and preparative $\mathrm{HPLC}\left(\mathrm{RP}-18, \mathrm{CH}_{3} \mathrm{CN}-\mathrm{H}_{2} \mathrm{O}\right.$ with $0.1 \%$ TFA, $50: 50 \rightarrow 70: 30)$. Starting from 5d (200 mg, $0.68 \mathrm{mmol}$ ), 31 was obtained as colorless solid (70 mg, 28\%). mp $162-163{ }^{\circ} \mathrm{C} ; R_{\mathrm{f}} 0.23$ (petroleum ether-ethyl acetate $70: 30$ ); UV/

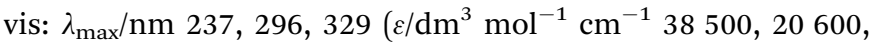
13 600); fluorescence: $\lambda_{\text {exc }}=303, \lambda_{\mathrm{em}}=443 \mathrm{~nm} ;{ }^{1} \mathrm{H}$ NMR (400 MHz; acetone- $\left.d_{6}\right) \delta$ ppm: $6.59\left(2 \mathrm{H}\right.$, br s, $\left.\mathrm{SO}_{2} \mathrm{NH}_{2}\right), 7.10-7.20(3 \mathrm{H}$, $\left.\mathrm{m},{ }^{3} J=8.9 \mathrm{~Hz},{ }^{3} J=7.5 \mathrm{~Hz}, 2 \mathrm{H}_{\text {phenyl }} / 1 \mathrm{H}_{\text {indol }}\right), 7.22\left(1 \mathrm{H}, \mathrm{dd},{ }^{3} J=\right.$ $\left.7.6 \mathrm{~Hz},{ }^{3} \mathrm{~J}=8.0 \mathrm{~Hz}, \mathrm{H}_{\text {indol }}\right), 7.49-7.59\left(5 \mathrm{H}, \mathrm{m},{ }^{3} \mathrm{~J}=8.9 \mathrm{~Hz},{ }^{3} \mathrm{~J}=8.5\right.$ $\left.\mathrm{Hz},{ }^{3} J=8.2 \mathrm{~Hz},{ }^{4} J=5.5 \mathrm{~Hz}, 4 \mathrm{H}_{\text {phenyl }} / 1 \mathrm{H}_{\text {indol }}\right), 7.64\left(1 \mathrm{H}, \mathrm{d},{ }^{3} J=\right.$ $\left.8.0 \mathrm{~Hz}, \mathrm{H}_{\text {indol }}\right), 7.91\left(2 \mathrm{H}, \mathrm{d},{ }^{3} J=8.6 \mathrm{~Hz}, \mathrm{H}_{\text {phenyl }}\right), 10.78(1 \mathrm{H}, \mathrm{br} \mathrm{s}$, $\mathrm{NH}) ;{ }^{13} \mathrm{C}$ NMR (101 MHz; acetone- $\left.d_{6}\right) \delta$ ppm: $112.4,113.5,116.5$ $\left(\mathrm{d},{ }^{2} J=22 \mathrm{~Hz}\right), 119.6,121.3,123.5,127.3,128.9,129.8\left(\mathrm{~d},{ }^{4} J=3\right.$ Hz), 130.9, 131.6 (d, $\left.{ }^{3} J=8 \mathrm{~Hz}\right), 135.3,137.5,140.4,142.5,163.3$ $\left(\mathrm{d},{ }^{1} J=246 \mathrm{~Hz}\right) ;{ }^{19} \mathrm{~F}$ NMR $\left(376 \mathrm{MHz}\right.$; acetone- $\left.d_{6}\right) \delta \mathrm{ppm}:-115.5$; ESI-MS $\left(\mathrm{ES}^{-}\right) \mathrm{m} / z: 365[\mathrm{M}-\mathrm{H}]^{-}(100 \%)$.

3-(4-Fluorophenyl)-5-methoxy-2-[4-(methylsulfonyl)phenyl]-1Hindole $(3 \mathrm{~m})$. A solution of $5 \mathrm{e}(0.524 \mathrm{~g}, 1.41 \mathrm{mmol})$ and freshly distilled 4-methoxyaniline $(0.745 \mathrm{~g}, 6.05 \mathrm{mmol})$ in ethanol (20 $\mathrm{mL}$ ) was heated to $170{ }^{\circ} \mathrm{C}$ for $34 \mathrm{~h}$ in a pressure stable glass vial. After that, the mixture was cooled to room temperature and the solvent was removed under reduced pressure. The resulting solid was suspended in ethyl acetate $(20 \mathrm{~mL})$, filtered, washed with ethanol ( $3 \mathrm{~mL}$ ) and dried. In this way, compound $3 \mathbf{m}$ was obtained as a yellow solid (197 mg, 37\%). mp $240-242{ }^{\circ} \mathrm{C} ; R_{\mathrm{f}} 0.29$ (petroleum ether-ethyl acetate $5: 5$ ); UV/vis: $\lambda_{\max } / \mathrm{nm} \mathrm{237,} 344$ $\left(\varepsilon / \mathrm{dm}^{3} \mathrm{~mol}^{-1} \mathrm{~cm}^{-1} 45\right.$ 200, 25400$)$; fluorescence: $\lambda_{\text {exc }}=349$, $\lambda_{\mathrm{em}}=484 \mathrm{~nm} ;{ }^{1} \mathrm{H}$ NMR $\left(400 \mathrm{MHz}\right.$; DMSO- $\left.d_{6}\right) \delta \mathrm{ppm}: 3.24(3 \mathrm{H}, \mathrm{s}$, $\left.\mathrm{SO}_{2} \mathrm{CH}_{3}\right), 3.73\left(3 \mathrm{H}, \mathrm{s}, \mathrm{OCH}_{3}\right), 6.82-6.94\left(2 \mathrm{H}, \mathrm{m}, \mathrm{H}_{\text {indole }}\right), 7.28$ $\left(2 \mathrm{H}, \mathrm{t},{ }^{3} \mathrm{~J}=8.9 \mathrm{~Hz}, \mathrm{H}_{\mathrm{F}-\mathrm{phenyl}-3 / 5}\right)$, 7.33-7.44 (3H, m, $\mathrm{H}_{\mathrm{F}-\mathrm{phenyl}-2 / 6} /$ $\left.\mathrm{H}_{\text {indole }}\right), 7.63\left(2 \mathrm{H}, \mathrm{d},{ }^{3} \mathrm{~J}=8.4 \mathrm{~Hz}, \mathrm{H}_{\text {SO2-phenyl }}\right), 7.89\left(2 \mathrm{H}, \mathrm{d},{ }^{3} J=8.5\right.$ $\mathrm{Hz}, \mathrm{H}_{\text {SO2-phenyl }}$ ), 11.65 (1H, s, NH); ${ }^{13} \mathrm{C}$ NMR (101 MHz; DMSO$\left.d_{6}\right) \delta$ ppm: 43.4, 55.3, 99.8, 112.6, 113.6, $114.1,115.9\left(\mathrm{~d},{ }^{2} J=21\right.$ 
$\mathrm{Hz}), 127.2,128.2,128.3,131.1\left(\mathrm{~d},{ }^{4} J=3 \mathrm{~Hz}\right), 131.7\left(\mathrm{~d},{ }^{3} \mathrm{~J}=8 \mathrm{~Hz}\right)$, 131.7, 132.6, 137.3, 139.1, 154.2, 161.0 (d, $\left.{ }^{1} \mathrm{~J}=243 \mathrm{~Hz}\right) ;{ }^{19} \mathrm{~F}$ NMR (376 MHz; DMSO- $d_{6}$ ) $\delta$ ppm: -116.4; ESI-MS (ES ${ }^{-}$) $m / z 394$ $[\mathrm{M}-\mathrm{H}]^{-}(100 \%)$.

\section{X-ray crystallography}

The crystallographic data were collected with a Bruker-Nonius Apex-X8 and Bruker-Nonius APEX-II CCD diffractometer, respectively, with Mo-K $\alpha$ radiation $(\lambda=0.71073 \AA)$. The structures were solved using SHELXS-97 and refined against $F^{2}$ on all data by full-matrix least squares with SHELXL-97. ${ }^{61}$ All nonhydrogen atoms were refined anisotropically; all hydrogen atoms bonded to carbon atoms were placed on geometrically calculated positions and refined using a riding model. $\$$

\section{LDL assay}

In order to determine redox activity-structure relationships of COX-2 inhibitors low-density lipoprotein (LDL) copper-/ironperoxidation models were used. Therefore, native albumin-free LDL (density 1.006-1.063 $\mathrm{g} \mathrm{mL}^{-1}$ ) were isolated from the blood plasma of healthy, normolipidemic, normoglycemic male volunteers by sequential very fast ultracentrifugation (VFU) and prepared for oxidation experiments as previously described by us in detail. ${ }^{62}$ Blood plasma and LDL were all processed in subdued light to prevent the photooxidation of LDL. All buffers and solutions were made oxygen-free by degassing and purging with argon. LDL apoB-100 was measured by immunoelectrophoresis using 'ready-to-use' agarose gels (Sebia, Issy-les-Moulineaux, France). Immediately before oxidation of LDL, EDTA, and salt from the density gradient were removed using a size exclusion column (Econo-Pac 10DG, Bio-Rad) and phosphatebuffered saline (PBS, $10 \mathrm{mM}$ sodium phosphate, $150 \mathrm{mM}$ sodium chloride, $\mathrm{pH} 7.4$ ) as the eluent. ${ }^{62}$

For lipid oxidation, to $200 \mu \mathrm{L}$-aliquots of native LDL $(125 \mu \mathrm{g}$ apoB-100/mL, equal to $0.25 \mu \mathrm{M}$ LDL) in 96 well plates (UV-Star plates, UV transparent to $200 \mathrm{~nm}$, Greiner, Germany) were added $25 \mu \mathrm{L}$ of an aqueous solution of $\mathrm{CuSO}_{4}(16 \mu \mathrm{M})$ and $25 \mu \mathrm{L}$ of the solution of the compound to be tested. All compounds (novel COX-2 inhibitors, celecoxib, quercetin, and melatonin) were tested at $1 \mu \mathrm{M}$ concentration. The same preparation without $\mathrm{CuSO}_{4}$ was used as control. The oxidative process was monitored using a Biotek Instruments Synergy 4 thermostatic $\mathrm{UV} / \mathrm{vis}$ micro plate reader by following the formation of conjugated dienes at $234 \mathrm{~nm}$ every $5 \mathrm{~min}$ for 4 hours at $30^{\circ} \mathrm{C}$. This approach results in a curve exhibiting a lag phase, during which the absorbance does not increase significantly, a propagation phase, during which the absorbance increases rapidly, and a degradation phase, characterized by a slow fall in the absorbance. ${ }^{\mathbf{6 3 , 6 4}}$ There is a positive (negative) correlation between lag phase duration and the concentration of antioxidants (prooxidants) contained in the LDL sample. ${ }^{63}$

For protein oxidation, aliquots of native LDL $(125 \mu \mathrm{g}$ apoB$100 / \mathrm{mL}$, equal to $0.25 \mu \mathrm{M} \mathrm{LDL}$ ) were subjected to a well characterized iron-catalyzed oxidation system containing $10 \mu \mathrm{M}$ bovine hemin chloride and $100 \mu \mathrm{M} \mathrm{H}_{2} \mathrm{O}_{2}$ at $37{ }^{\circ} \mathrm{C}$ for 40 hours in the dark. ${ }^{65}$ The oxidative process was monitored by mass spectrometric determination of formation of $\gamma$-glutamyl semialdehyde, a specific product of protein oxidation, which by reduction forms 5-hydroxy-2-aminovaleric acid (HAVA) as described elsewhere in detail. ${ }^{65,66}$

In this study the results are expressed as ratios between the duration of lag phase in the presence and in the absence of the compound ( $\left.R_{\text {DIENE }}\right)$ and between the apoB-100 HAVA content in the absence and in the presence of the compound $\left(R_{\text {HAVA }}\right)$. Thus, in both approaches $R$ values ( $R_{\text {DIENE }}$ or $\left.R_{\text {HAVA }}\right)$ higher than 1 indicate antioxidant activity, $R$ values of about 1 mean that the compound has no effect and $R$ values lower than 1 suggests prooxidant activity.

\section{COX inhibitory assay}

The COX inhibition activity against ovine COX-1 and human COX-2 presented in Table 2 was determined at the given concentrations using the fluorescence based COX assay "COX Fluorescent Inhibitor Screening Assay Kit" (catalog number 700100; Cayman Chemical, Ann Arbor, MI, USA) and the EIA based COX assay "COX inhibitor Screening Assay Kit" (catalog number 560131; Cayman Chemical, Ann Arbor, MI, USA) according to the manufacturer's instructions.

\section{Acknowledgements}

The authors thank the Helmholtz Association for funding a part of this work through Helmholtz-Portfolio Topic "Technologie und Medizin - Multimodale Bildgebung zur Aufklärung des In vivoVerhaltens von polymeren Biomaterialien". This work is also part of the research initiative "Radiation-Induced Vascular Dysfunction (RIVAD)". The excellent technical assistance of Peggy Wecke, Mareike Barth, Catharina Heinig, and Sebastian Meister is greatly acknowledged. Franz-Jacob Pietzsch is graduate student member of the Integrated Research Training Group "Matrixengineering" (within the Transregional Collaborative Research Centre 67 "Functional biomaterials for controlling healing processes in bone and skin - from material science to clinical application" funded by German Research Foundation) at Medical Faculty and University Hospital Carl Gustav Carus, Technische Universität, Dresden.

\section{References}

1 L. J. Marnett, Annu. Rev. Pharmacol. Toxicol., 2009, 49, 265290.

2 P. Singh and A. Mittal, Mini-Rev. Med. Chem., 2008, 8, 73-90. 3 N. Chandna, J. K. Kapoor, J. Grover, K. Bairwa, V. Goyal and S. M. Jachak, New J. Chem., 2014, 38, 3662-3672.

4 W. C. Black, C. Bayly, M. Belley, C. Chan, S. Charleson, D. Denis, J. Y. Gauthier, R. Gordon, D. Guay, S. Kargman, C. K. Lau, Y. Leblanc, J. Mancini, M. Ouellet, D. Percival, P. Roy, K. Skorey, P. Tagari, P. Vickers, E. Wong, L. Xu and P. Prasit, Bioorg. Med. Chem. Lett., 1996, 6, 725-730.

5 S. Olgen, E. Akaho and D. Nebioglu, Eur. J. Med. Chem., 2001, 36, 747-770. 
6 J. A. Campbell, C. A. Broka, L. Gong, K. A. M. Walker and J. Wang, Tetrahedron Lett., 2004, 45, 4073-4075.

7 J. A. Campbell, V. Bordunov, C. A. Broka, M. F. Browner, J. M. Kress, T. Mirzadegan, C. Ramesha, B. F. Sanpablo, R. Stabler, P. Takahara, A. Villasenor, K. A. M. Walker, J. Wang, M. Welch and P. Weller, Bioorg. Med. Chem. Lett., 2004, 14, 4741-4745.

8 J. A. Campbell, V. Bordunov, C. A. Broka, J. Dankwardt, R. T. Hendricks, J. M. Kress, K. A. M. Walker and J. Wang, Tetrahedron Lett., 2004, 45, 3793-3796.

9 W. Hu, Z. Guo, F. Chu, A. Bai, X. Yi, G. Cheng and J. Li, Bioorg. Med. Chem., 2003, 11, 1153-1160.

10 W. Hu, Z. Guo, X. Yi, C. Guo, F. Chu and G. Cheng, Bioorg. Med. Chem., 2003, 11, 5539-5544.

11 Z. Guo, G. Cheng and F. Chu, US Pat., 20040058977 A1, 2004. 12 M. S. Estevão, L. C. R. Carvalho, M. Freitas, A. Gomes, A. Viegas, J. Manso, S. Erhardt, E. Fernandes, E. J. Cabrita and M. M. B. Marques, Eur. J. Med. Chem., 2012, 54, 823-833.

13 J. Kaur, A. Bhardwaj, Z. Huang and E. E. Knaus, Bioorg. Med. Chem. Lett., 2012, 22, 2154-2159.

14 B. B. Aggarwal and P. Gehlot, Curr. Opin. Pharmacol., 2009, 9, 351-369.

15 Z. Liao, K. A. Mason and L. Milas, Drugs, 2007, 67, 821-845. 16 M. R. Becker, M. D. Siegelin, R. Rompel, A. H. Enk and T. Gaiser, Melanoma Res., 2009, 19, 8-16.

17 C. Tondera, M. Laube, C. Wimmer, T. Kniess, B. Mosch, K. Großmann and J. Pietzsch, Biochem. Biophys. Res. Commun., 2013, 430, 301-306.

18 L. T. Soumaoro, H. Uetake, T. Higuchi, Y. Takagi, M. Enomoto and K. Sugihara, Clin. Cancer Res., 2004, 10, 8465-8471.

19 A. M. Minisini, G. Pascoletti, D. Intersimone, E. Poletto, P. Driol, R. Spizzo, C. A. Scott, F. Puglisi, G. Fasola and C. Di Loreto, Melanoma Res., 2013, 23, 96-101.

20 S. Meyer, T. J. Fuchs, A. K. Bosserhoff, F. Hofstadter, A. Pauer, V. Roth, J. M. Buhmann, I. Moll, N. Anagnostou, J. M. Brandner, K. Ikenberg, H. Moch, M. Landthaler, T. Vogt and P. J. Wild, PLoS One, 2012, 7, e38222.

21 P. Zhan, Q. Qian and L. K. Yu, J. Thorac. Dis., 2013, 5, 40-47. 22 D. Hanahan and R. A. Weinberg, Cell, 2011, 144, 646-674.

23 E. F. de Vries, Curr. Pharm. Des., 2006, 12, 3847-3856.

24 M. Laube, T. Kniess and J. Pietzsch, Molecules, 2013, 18, 6311-6355.

25 O. Tietz, A. Marshall, M. Wuest, M. Wang and F. Wuest, Curr. Med. Chem., 2013, 20, 4350-4369.

26 J. Prabhakaran, M. D. Underwood, R. V. Parsey, V. Arango, V. J. Majo, N. R. Simpson, R. Van Heertum, J. J. Mann and J. S. Kumar, Bioorg. Med. Chem., 2007, 15, 1802-1807.

27 E. F. de Vries, J. Doorduin, R. A. Dierckx and A. van Waarde, Nucl. Med. Biol., 2008, 35, 35-42.

28 M. J. Uddin, B. C. Crews, K. Ghebreselasie, I. Huda, P. J. Kingsley, M. S. Ansari, M. N. Tantawy, J. J. Reese and L. J. Marnett, Cancer Prev. Res., 2011, 4, 1536-1545.

29 D. D. Nolting, M. Nickels, M. N. Tantawy, J. Y. H. Yu, J. Xie, T. E. Peterson, B. A. Crews, L. Marnett, J. C. Gore and W. Pham, Front. Oncol., 2013, 2, 207, DOI: 10.3389/ fonc.2012.00207.
30 T. Kniess, M. Laube, R. Bergmann, F. Sehn, F. Graf, J. Steinbach, F. Wuest and J. Pietzsch, Bioorg. Med. Chem., 2012, 20, 3410-3421.

31 M. Mor, G. Spadoni, G. Diamantini, A. Bedini, G. Tarzia, C. Silva, F. Vacondio, M. Rivara, P. Plazzi, D. Franceschinit, M. Zussot and P. Giusti, Adv. Exp. Med. Biol., 2003, 527, 567-575.

32 S. Suzen, S. S. Cihaner and T. Coban, Chem. Biol. Drug Des., 2012, 79, 76-83.

33 D. P. Kudav, S. P. Samant and B. D. Hosangadi, Synth. Commun., 1987, 17, 1185-1187.

34 A. Trejo, H. Arzeno, M. Browner, S. Chanda, S. Cheng, D. D. Comer, S. A. Dalrymple, P. Dunten, J. Lafargue, B. Lovejoy, J. Freire-Moar, J. Lim, J. Mcintosh, J. Miller, E. Papp, D. Reuter, R. Roberts, F. Sanpablo, J. Saunders, K. Song, A. Villasenor, S. D. Warren, M. Welch, P. Weller, P. E. Whiteley, L. Zeng and D. M. Goldstein, J. Med. Chem., 2003, 46, 4702-4713.

35 C. J. Dinsmore and J. M. Bergman, PCT Int. Appl., WO2005030129 A2, 2005.

36 N. Mathews, R. A. Ward and A. J. Whitehead, US-Pat., 6803463 B2, 2004.

37 S. K. Singh, V. Saibaba, V. Ravikumar, S. V. Rudrawar, P. Daga, C. S. Rao, V. Akhila, P. Hegde and Y. K. Rao, Bioorg. Med. Chem., 2004, 12, 1881-1893.

38 J. J. Talley, S. Bertenshaw, D. J. Rogier Jr, M. Graneto, D. L. Brown, B. Devadas, H. Lu and J. A. Sikorski, PCT Int. Appl., WO9636617 A1, 1996.

39 M. Laube, W. Neumann, M. Scholz, P. Lönnecke, B. Crews, L. J. Marnett, J. Pietzsch, T. Kniess and E. Hey-Hawkins, ChemMedChem, 2013, 8, 329-335.

40 Y. Vara, E. Aldaba, A. Arrieta, J. L. Pizarro, M. I. Arriortua and F. P. Cossio, Org. Biomol. Chem., 2008, 6, 1763-1772.

41 V. Sridharan, S. Perumal, C. Avendaño and J. C. Menéndez, Synlett, 2006, 91-95.

42 C. Farrerons Gallemi, I.-J. Miquel Bono, A. M. Fernandez Serrat, C. Monserrat Vidal, C. Lagunas Arnal, F. Gimenez Guasch and A. Fernandez Garcia, PCT Int. Appl., WO 2000008024 A1, 2000.

43 M. Miyasaka, A. Fukushima, T. Satoh, K. Hirano and M. Miura, Chem.-Eur. J., 2009, 15, 3674-3677.

44 S. D. Koulocheri and S. A. Haroutounian, Eur. J. Org. Chem., 2001, 2001, 1723-1729.

45 D. L. Horrocks, J. Chem. Phys., 1968, 49, 2913-2917.

46 I. B. Berlman, Spectrochim. Acta, Part A, 1971, 27, 473-489.

47 D. G. Kaiser, B. J. Bowman and A. A. Forist, Anal. Chem., 1966, 38, 977-980.

48 P. Prasit, D. Guay, Z. Wang, S. Leger and M. Therien, PCT Int. Appl., WO 9606840 A1, 1996.

49 M. W. Tabor, E. Coats, M. Sainsbury and H. G. Shertzer, Adv. Exp. Med. Biol., 1991, 283, 833-836.

50 E. A. Lissi, M. Faure, N. Montoya and L. A. Videla, Free Radical Res. Commun., 1991, 15, 211-222.

51 J. Pietzsch, M. Laube, F. J. Pietzsch, R. Bergmann and T. Kniess, in Coronary Artery Disease: 2011 Update, ed. B. S. Lewis, M. Y. Flugelman and D. A. Halon, Medimond S.r.1 - 
Monduzzi Editore International, Bologna, Italy, 2011, pp. 107-110.

52 S. Ullm, F. Sehn, M. Laube, C. Tondera, N. Bechmann, B. Mosch, T. Kniess and J. Pietzsch, in Proceedings of the 6th European Congress of Pharmacology, ed. A. Zarzuelo and R. Jimenez, Medimond S.r.l - Monduzzi Editore International, Pianoro (Bologna), Italy, 2013, pp. 87-90.

53 S. Suzen, P. Bozkaya, T. Coban and D. Nebiogu, J. Enzyme Inhib. Med. Chem., 2006, 21, 405-411.

54 A. Gozzo, D. Lesieur, P. Duriez, J. C. Fruchart and E. Teissier, Free Radical Res. Commun., 1999, 26, 1538-1543.

55 M. F. Walter, R. F. Jacob, C. A. Day, R. Dahlborg, Y. Weng and R. P. Mason, Atherosclerosis, 2004, 177, 235-243.

56 Y. Kuge, Y. Katada, S. Shimonaka, T. Temma, H. Kimura, Y. Kiyono, C. Yokota, K. Minematsu, K. Seki, N. Tamaki, K. Ohkura and H. Saji, Nucl. Med. Biol., 2006, 33, 21-27.

57 M. Tanaka, Y. Fujisaki, K. Kawamura, K. Ishiwata, Q. GeLeTu, F. Yamamoto, T. Mukai and M. Maeda, Biol. Pharm. Bull., 2006, 29, 2087-2094.
58 M. S. Morales-Ríos, J. Espiñeira and P. Joseph-Nathan, Magn. Reson. Chem., 1987, 25, 377-395.

59 K. Kobayashi, S. Fujita, S. Fukamachi and H. Konishi, Synthesis, 2009, 3378-3382.

60 M. C. Wilkinson, Org. Lett., 2011, 13, 2232-2235.

61 (a) G. M. Sheldrick, Acta Crystallogr., Sect. A: Found. Crystallogr., 2008, 64, 112-122; (b) G. M. Sheldrick, SHELXS/L-97, Programs for the Solutions and Refinements of Crystal Structures, University of Göttingen, Göttingen, 1997.

62 J. Pietzsch, R. Bergmann, K. Rode, C. Hultsch, B. Pawelke, F. Wuest and J. van den Hoff, Nucl. Med. Biol., 2004, 31, 1043-1050.

63 H. Esterbauer, G. Striegl, H. Puhl and M. Rotheneder, Free Radical Res. Commun., 1989, 6, 67-75.

64 S. Kopprasch, W. Leonhardt, J. Pietzsch and H. Kühne, Atherosclerosis, 1998, 136, 315-324.

65 J. Pietzsch, Biochem. Biophys. Res. Commun., 2000, 270, 852857.

66 J. Pietzsch, F. J. Pietzsch and S. Kopprasch, Trends Chromatogr., 2009, 5, 15-20. 